\title{
Review of Studies on Phlomis and Eremostachys Species (Lamiaceae) with Emphasis on Iridoids, Phenylethanoid Glycosides, and Essential Oils
}

Authors
insan Çalış

Affiliation

Near East University, Faculty of Pharmacy, Department of Pharmacognosy, Lefkoşa (Nicosia), TRNC

Key words

Phlomis, Eremostachys, Lamiaceae, Phlomideae, secondary metabolites, iridoids, phenylethanoids, essential oils

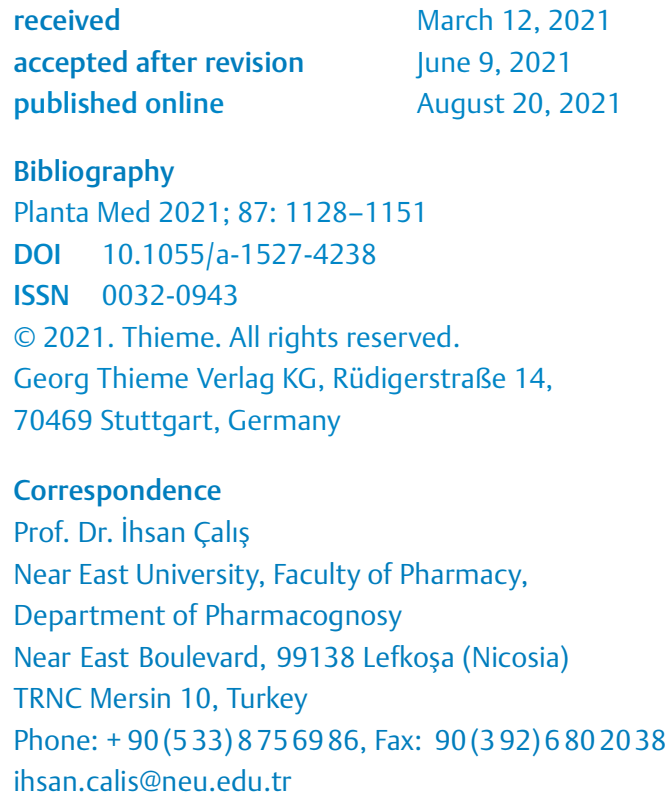

ABSTRACT

As the sixth-largest Angiosperm family, Lamiaceae contains more than 245 genera and 7886 species that are distributed worldwide. It is also the third-largest family based on the number of taxa in Turkey where it is represented by 46 genera and 782 taxa with a high endemism ratio (44\%). Besides, Lamiaceae are rich in plants with economic and medicinal value containing volatile and nonvolatile compounds. Many aromatic plants of Lamiaceae such as Salvia, Sideritis, Stachys, Phlomis, and Teucrium species are used in traditional herbal medicine throughout Turkey as well as in other Mediterranean countries. Salvia (Sage tea "Adaçayı"), Sideritis (Mountain tea "Dağçayı"), Stachys (Hairy Tea "Tüylü Çay”), and Phlomis (Turkish sage "Çalba or Şalba") are the largest genera that are used as herbal teas. This review focuses on the volatile and nonvolatile compounds of Lamiaceae from the genera Phlomis and Eremostachys of the subfamily Lamioideae with emphasis on iridoids, phenylethanoid glycosides, and essential oils.

\section{Introduction}

As the sixth-largest Angiosperm family, Lamiaceae contains more than 245 genera and 7886 species distributed worldwide. It is also the third-largest family based on the number of taxa in Turkey. In Turkey, the family Lamiaceae comprises 46 genera and 782 taxa (603 species, 179 subspecies and varieties), of which 346 taxa (271 species, 75 subspecies and varieties) (ca. 44\%) are endemic. There are 28 hybrid species, 24 of which are endemic. Stachys L. (118 taxa), Salvia L. (107 taxa), Sideritis L. (54 taxa), Phlomis L. (53 taxa), and Teucrium L. (49 taxa) are the largest 5 genera. Approximately $72 \%$ of the species are found in the largest 10 genera, while 15 genera are monotypic [1]. Lamiaceae are rich in plants with high economic and medicinal value due to essential oils and other active constituents. In the early 1990s, research focused mainly on the constituents of the essential oils including monoand sesquiterpenes. With the advancement of spectroscopic techniques, a great variety of nonvolatile isoprenoids with diand triterpenoid structures (free or glycosylated derivatives) and ecdysteroids were reported as constituents responsible for a wide range of biological activities. Iridoids and monoterpene lactones are nonvolatile glycosidic isoprenoids. The occurrence of iridoids in certain subfamilies has been of major taxonomic interest. Additionally, phenolic compounds, flavonoids (flavones, flavonols, flavanones, dihydroflavonols, chalcones), anthocyanins (cyanidin, delphinidin, malvidin, pelargonidin glycosides, and their acylated derivatives), and caffeoyl ester glycosides were attractive targets

\# Dedicated to Prof. Dr. Otto Sticher on the occasion of his 85th birthday. 


$\begin{array}{ll}\text { ABBREVIATIONS } \\ \text { 5-HETE } & \text { 5-Hydroxyeicosatetraenoic acid } \\ \text { ACP } & \text { acyl carrier protein } \\ \text { CAMP } & \text { cyclic adenosine monophosphate } \\ \text { dRLh-88 } & \text { rat hepatoma } \\ \text { FMPL } & \text { N-formyl-methionyl-leucyl-phenylalanine } \\ \text { GR } & \text { glutathione reductase } \\ \text { H460 } & \text { human large cell carcinoma of the lung } \\ \text { HeLa } & \text { human epithelial carcinoma } \\ \text { HL-60 } & \text { cells human promyelocytic leukemia cell line } \\ \text { L-DOPA } & \text { L-3,4-dihydroxyphenylalanine } \\ \text { MCF } & \text { 7 multidrug-resistant human breast cancer } \\ & \text { subline } \\ \text { NCI } & \text { (US) National Cancer Institute } \\ \text { P-388-D1 } & \text { mouse lymphoid neoplasm } \\ \text { Ph. } & \text { Phlomis } \\ \text { PhEts } & \text { phenylethanoid glycosides } \\ \text { PMNs } & \text { polymorphonuclear neutrophils } \\ \text { ROS } & \text { reactive oxygen species } \\ \text { S-180 } & \text { sarcoma cells } \\ \text { SF-268 } & \text { central nervous system cancer cell lines } \\ & \end{array}$

for many research groups because of their taxonomic significance and biological and pharmacological activities [2]. The high biological diversity in terms of the number of taxa, together with the large proportion of plants used traditionally, triggered phytochemical and pharmacognostical studies in drug discovery.

\section{Initial Studies}

The research interest in iridoids, as well as other chemical constituents of Lamiaceae plants, goes back to the year 1982 for one of the authors of this work (IC). Galeopsis pubescens was one of the species studied for iridoids by E. Rogenmoser at the Swiss Federal Institute of Technology (ETHZ) in the group of Prof. Sticher [3]. Iridoids such as daunoside, harpagide, acetylharpagide, and galiridoside had been reported from G. pubescens. A study performed on yet uncharacterized fractions of $G$. pubescens resulted in the isolation of 2 phenylethanoid glycosides (PhEts), martynoside and isomartynoside [4]. These 2 metabolites showed close similarity to the caffeic acid derivatives reported in higher plants by Harborne [5]. It was suggested that caffeic esters might be of considerable value in chemotaxonomic studies. The distribution of rosmarinic acid and orobanchin has been studied concerning their occurrence in some Tubiflorae. Orobanchin was described as a derivative of caffeic acid, 3,4-dihydroxyphenylethanol, glucose, and rhamnose, and had only been reported as a constituent of Orobanche minor (Orobanchaceae). In fact, the first studies on caffeoyl sugar esters go back to the 1950s. Echinacoside, a triglycosidic phenylethanoid isolated from Echinacea angustifolia (Asteraceae) in 1950 was structurally determined in 1983, while verbascoside first isolated in 1963 was structurally determined in 1968 [6].
The coexistence of iridoids and phenylethanoid glycosides in some plants of Tubiflorae led us to focus our research on randomly selected plants of Lamiaceae and Scrophulariaceae. Both compound groups have been suggested as being of considerable value in chemotaxonomic studies. Thus, studies have been initiated on plants such as Scrophularia scopolii (Scrophulariaceae) [7-9], Betonica officinalis (Lamiaceae) [10], Stachys lavandulifolia (Lamiaceae) [11], Phlomis linearis (Lamiaceae) [12-14], P. bourgaei [15-16], Pedicularis species (Scrophulariaceae) [17], Lagotis stolonifera (Scrophulariaceae) [18] Phlomis armeniaca, and Scutellaria salviiifolia [19], yielding iridoid and phenylethanoid glycosides. In contrast to the presence of a majority of aucubine-type iridoids in Scrophulariaceae, loganin-type iridoids were mostly detected and identified in Lamiaceae plants.

The Lamiaceae (Labiatae) Congress of 1991 at Royal Botanic Gardens, Kew, London has been a milestone for future studies. Ajugoideae, Chloanthoideae, Lamioideae, Nepetoideae, Pogostomonoideae, Scutellarioidea, Teucrioideae, and Viticoideae were declared as 8 subfamilies of Lamiaceae [20]. At this congress, the family Lamiaceae was discussed in the light of biogeography and phylogenetic relationships, systematic studies of selected characters and groups, biology, chromosome numbers and breeding system, chemical constituents, plant-insect interactions, and the economics of genera.

During the last 2 decades, the aspects and classification of various members of Lamiaceae have been investigated both chemotaxonomically and systematically. In 1999, 96 Lamiaceae taxa have been investigated for the presence of rosmarinic and caffeic acids [21]. Rosmarinic acid was found in all species of the subfamily Nepetoideae but was absent from those in the subfamily Lamioideae. However, Lamioideae species were rich in caffeic acid. In 2000, Pedersen studied 110 genera of Lamiaceae (Labiatae) for 2 chemical characters giving support to the subfamily division of the Lamiaceae [22]. Within the 2 large subfamilies, the genera of Lamioideae, rich in iridoids, were reported to contain phenylethanoid glycosides and to possess tricolpate pollen grains, while the genera of Nepetoidea that contain a higher amount of essential oils were reported to contain rosmarinic acid and were found to possess hexacolpate pollen grains. In 2017, 2 new subfamilies have been included in the Lamiaceae: Callicarpoideae (170 Callicarpa species) and Tectonoideae (3 Tectona species) [23]. According to recent studies, 12 subfamilies are recognized in Lamiaceae: Ajugoideae, Lamioideae, Nepetoideae, Prostantheroideae, Scutellarioideae, Symphorematoideae, Viticoideae. Cymarioideae, Peronematoideae, Premnoideae, Callicarpoideae, and Tectonoideae $[1,24,25]$. Thus, systematic studies strongly supported a rich diversity of Lamiaceae in many aspects including their chemical constituents. In the Flora of Turkey, Ajugoideae, Lamioideae, Nepetoideae, Scutellarioideae, and Viticoideae are the subfamilies of Lamiaceae that are represented by 48 genera and 782 taxa with a high degree of endemism (ca. 44\%). Stachys (118 taxa), Salvia (107 taxa), Sideritis (54 taxa), Phlomis (53 taxa), and Teucrium (49 taxa) are the largest 5 genera that show high endemism ( $\bullet \mathbf{T a}$ ble 1) $[1,26]$. The members of this family are known as culinary, flavoring herbs or herbal teas, many of them native to Turkey as well as the Mediterranean area and many subtropical semi-arid zones worldwide. 
- Table 1 The subfamilies of Lamiaceae and the genera recorded in the Flora of Turkey.*

\begin{tabular}{|c|c|c|}
\hline Subfamilies & Tribes & Genera \\
\hline \multirow[t]{6}{*}{ Lamioideae } & Lamieae & Lamium \\
\hline & Marrubieae & Ballota, Marrubium, Pseudodictamnus Molucella \\
\hline & Leonureae & Leonurus, Chaiturus \\
\hline & Phlomideae & Phlomis, Eremostachys, Phlomoides \\
\hline & Stachydeae & Stachys, Sideritis, Prasium, Melittis \\
\hline & Galeopseae & Galeopsis \\
\hline Scutellarioideae & & Scutellaria \\
\hline \multirow[t]{3}{*}{ Ajugoideae } & Ajugeae & Ajuga \\
\hline & Clerodendreae & Clerodendrum \\
\hline & Teucrieae & Teucrium \\
\hline Viticoideae & & Vitex \\
\hline \multirow[t]{3}{*}{ Nepetoidea } & Mentheae & $\begin{array}{l}\text { Mentha, Clinopodium, Melissa, Nepeta, Lophantus, Origanum, Thymus, Salvia, Hyssopus, } \\
\text { Prunella, Lycopus, Dracocephalum, Glechoma, Thymbra, Satureja, Pentapleura, Ziziphora, } \\
\text { Cyclotrichium, Micromeria, Hymenocrater, Lallemantia }\end{array}$ \\
\hline & Ocimeae & Ocimum, Hyptis, Lavandula \\
\hline & Elsholtzieae & Elsholtzia, Perilla \\
\hline
\end{tabular}

Our phytochemical and chemotaxonomic studies focused on the genus level of the members of tribes in Lamioideae (Lamieae: Lamium; Marrubieae: Marrubium, Molucella; Leonureae: Leonurus; Phlomideae: Phlomis, Eremostachys; Stachydeae: Stachys, Sideritis, Prasium; Galeopseae: Galeopsis), Scutellarioideae (Scutellaria), Ajugoideae (Ajugeae: Ajuga; Clerodenreae: Clerodendrum; Teucrieae: Teucrium) for iridoid and PhEts contents. The present review gives a detailed overview of the results from the studies performed on the species of genus Phlomis L. and Eremostachys Bunge from the Phlomideae tribe of the subfamily Lamioideae.

\section{Phlomideae}

\section{Phlomis species}

Unlike other genera, the genus Phlomis has been studied in detail for all of its species. In the frame of a project focused on the chemotaxonomy of the genus Phlomis, species recorded in the flora of Turkey were studied for their secondary metabolites with emphasis on iridoids and PhEts [27].

Phlomis species are perennial herbs or small shrubs, pilose or tomentose. Morphological characters are verticillasters few- to many-flowered, crowded or distant in the axil of floral leaves, bracteoles absent, few or numerous, subulate to ovate. Thirtythree Phlomis species recorded in the flora of Turkey have been divided into 3 groups. The species in Group A have a pink or purple corolla. Groups B and C have a yellow corolla, sometimes with brownish upper lip, the former being shrubs or herbs with numerous bracteoles, the latter being herbs having few or no bracteoles ( $\bullet$ Fig. 1) [25].

\section{Iridoids}

Throughout these studies, 21 iridoid glucosides (1-21) have been isolated ( $\triangleright$ Fig. 2) [12-14, 19, 27-51]. Phlorogidosides A, B, and C $(12,19$, and 20$)$ have been reported from Ph. rigida [52]. Phlorogidoside $C$ was also reported from Ph. tuberosa and named as 5deoxysesamoside (12) in the same year [53]. Caryoptoside (21) was recently isolated from $P h$. brevibracteata which is one of the 3 species growing in Cyprus [54]. This was the first record for caryoptoside in Phlomis species. Auroside (1), lamiide (3), and ipolamiide (4) were also isolated from $P$ h. floccosa collected from Libya [55].

All of the iridoids isolated from Phlomis species have a monoglucosidic structure. Auroside (1), lamiide (3), and ipolamiide (4) have been encountered in most Phlomis species ( $\bullet$ Table 2 ). Brunneaogaleatoside (16) and lamiidoside (17) are $p$-coumaroyl ester derivatives. Among the iridoids isolated, 7-epi-lamalbide (6), ipolamiidic acid (13), lamiidic acid (14), 8-O-acetyl-shanzhizide (15), brunneogaleatoside (16), and chlorotuberoside (18) were described for the first time.

Structurally, iridoids isolated from Phlomis species can be classified into 4 groups, A, B, C, and D. Compounds 3-6, 8-10, 17-21 $\left(A_{1}\right)$, and 13-15 $\left(A_{2}\right)$ are mussaenoside derivatives. In subgroup $A_{1}$, the $\mathrm{COOH}$ group located at $\mathrm{C}-4$ is found as methyl ester. Sesamoside (11) and 5-deoxysesamoside (phlorogidoside C) (12) are oxygenated at $C-8$ as in groups $A_{1}$ and $A_{2}$ but form an epoxy functionality with C-7 building Group B. Compound 1, 2, and 7 are 8epi-loganin derivatives with a secondary methyl group at C-8 (Group C). Group D is represented by only 1 compound, brunneogaleatoside (16), in which the double bond in the pyrane ring is located between C-4 and C-5, unlike in most iridoids. Further oxy- 


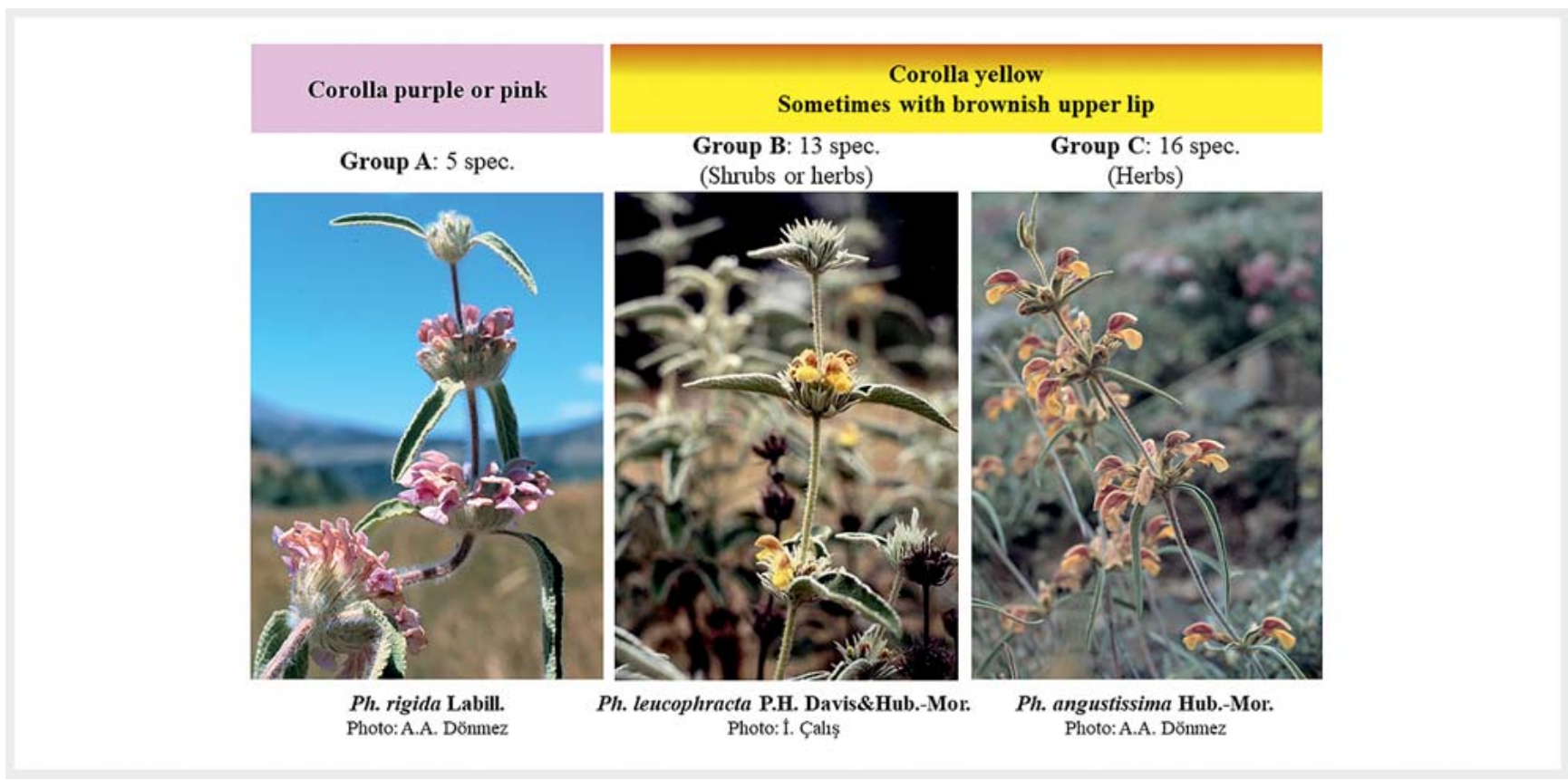

- Fig. 1 Classification of Phlomis species in the Flora of Turkey and the East Aegean Islands.

genation patterns are observed at the $\mathrm{C}-5, \mathrm{C}-6$, and $\mathrm{C}-7$ positions in groups A, B, and C ( Fig. 3). Only 1 iridoid (18) is chlorinated.

The distribution of the iridoids in the Phlomis species is given in - Table 2. As seen in this table, Ph. tuberosa is the richest species and is completely different from the other species with regard to its iridoid content. 7-epi-Phlomiol (10), sesamoside (11), and 8-Oacetyl-shanzhizide (15) were only isolated from $P$ h. tuberosa. Furthermore, lamiide (3), ipolamiide (4), common iridoids for most of the Phlomis species, were not found in Ph. tuberosa. Lamiide (3) was identified in 20 species while ipolamiide (4) was found in 11 species. On the other hand, 3 and 4 were found together in 6 species. Eight iridoids-ipolamiidic acid (13), lamiidic acid (14), 8-O-acetyl-shanzhizide (15), brunneogaleatoside (16), lamiidoside (17), chlorotuberoside (18), and phlorigidosides A and B (19 and 20)-were reported only in 1 or 2 species.

\section{Phenylethanoid glycosides}

From Phlomis species, 35 PhEt glycosides were isolated (22-56) ( $\triangleright$ Figs. 4-6) which can be classified under 11 main groups (A-K) according to the glycosidation patterns and include di-, tri-, and tetraglycosides ( $\triangleright$ Tables $3-6)$. Diglycosides are classified into 3 groups ( $A, B$, and $C$ ). Group A consists of verbascoside and its derivatives (22-28) with 3-O-( $\alpha$-L-rhamnopyranosyl)- $\beta$-D-glucopyranoside as oligosaccharide moiety. Group B comprises only 1 compound, $\beta$-hydroxyacteoside (29), possessing the same oligosaccharide but a different aglycone, 3,4-dihydoxyphenyl-2-hydroxyethanol. Group $C$, which is rarely observed, has a different oligosaccharide moiety, 2-O-( $\beta$-D-apiofuranosyl)- $\beta$-D-glucopyranoside, 4-hydroxy-phenylethanol as aglycone and vanillic acid as ester moiety (31-32).
Five groups (D-H) are triglycosidic PhEts (33-53). Forsythoside B (33), samioside (37), myricoside (40), echinacoside (43), and phlinoside A (47) are representative compounds for each group that show different sites of attachment of the third sugar linked to the core 3-O-( $\alpha$-L-rhamnopyranosyl)- $\beta$-D-glucopyranoside disaccharidic moiety.

\section{Tri- and tetraglycosidic phenylethanoids (33-55)}

\section{- Table 4.}

\section{Simple phenol glycoside (56)}

Two tetraglycosidic PhEts, physocalycoside (54) and lunarifolioside (55), are representatives of 2 separate groups (I and J). Seguinoside $\mathrm{K}(56)$ is a simple phenol or hydroquinone glycoside, which is regarded as belonging to a further group (K) of PhEts since the aglycone and ester moieties are formed via the shikimate pathway as in other PhEts.

Phenylethanoid glycosides grouped according to glycosidation patterns are reported in $\mathbf{r}$ Table $\mathbf{5}$, and the distribution of PhEt groups (A-K) in Phlomis species is given in > Table 6.

Among the diglycosides (Group A), verbascoside (= acteoside) (23) was found in all Phlomis species. $\beta$-Hydroxyacteoside (Group B) was isolated from Ph. viscosa, Ph. siehana, and Ph. syriaca. Among the triglycosides, a member of Group D, forsythoside B (33), is the most common PhEt together with verbascoside (23) found in all the species. PhEts of Groups E, F, G, and $\mathrm{H}$ were observed in a very limited number of Phlomis species. In Groups E, $\mathrm{F}$, and $\mathrm{H}$, the third sugar is attached to the secondary hydroxyl groups, $\mathrm{C}-4(\mathrm{OH}), \mathrm{C}-3(\mathrm{OH})$, or $\mathrm{C}-2(\mathrm{OH})$ of the rhamnopyranose unit, respectively. In the subgroups of $\mathrm{G}_{1}$ and $\mathrm{G}_{2}$, the third sugar is glucose or xylose. The subgroups $\mathrm{H}_{1}, \mathrm{H}_{2}, \mathrm{H}_{3}$, and $\mathrm{H}_{4}$ differ from 


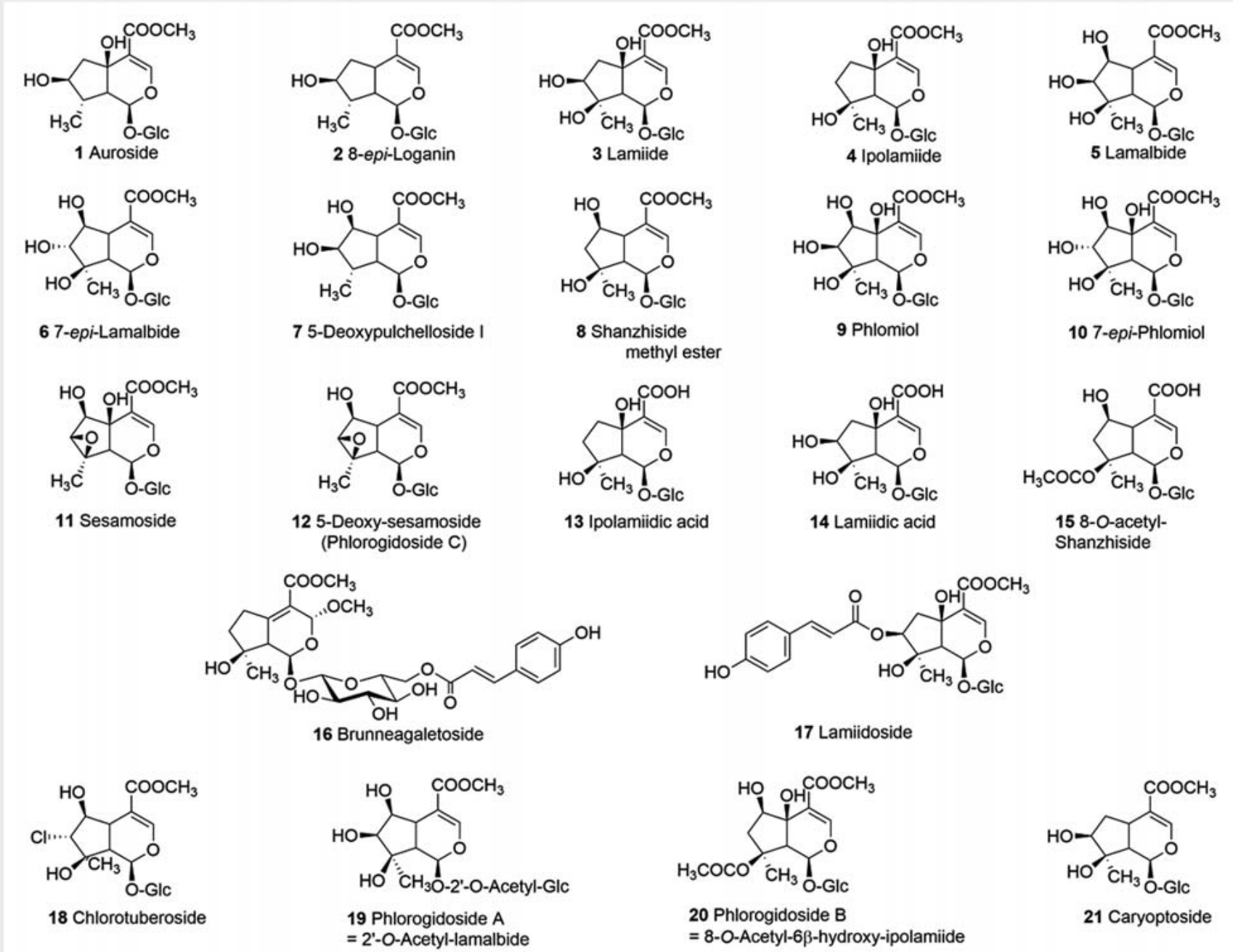

- Fig. 2 Iridoids isolated from Phlomis species (1-21).

each other by the type of the third sugar, which is glucose, xylose, rhamnose, or lyxose, respectively. Phlinosides A-E (47-52) and teucrioside (53), classified in the subgroups of $\mathrm{H}_{1}, \mathrm{H}_{2}, \mathrm{H}_{3}$, and $\mathrm{H}_{4}$, were isolated from $P h$. linearis $[12,13]$. Teucrioside (53), bearing a very rare pentose, $\alpha$-L-lyxose, and representing subgroup $\mathrm{H}_{4}$ was isolated only from Ph. armeniaca [19].

In groups $D, G_{1}$, and $G_{2}$, the glycosidation site of the third sugar is the primary hydroxyl function $[(-6[\mathrm{OH}])$ of the core sugar glucopyranose. Throughout these studies, only 2 tetraglycosidic phenylethanoid glycosides, physocalycoside (54) and lunarifolioside (55), were isolated from $P$. physocalyx [36] and $P$. lunariifolia [42]. In both compounds, the glycosidation sites of the third and fourth sugar units are on the primary hydroxyl group of the core sugar, glucose, and on one of the secondary hydroxyl groups of the rhamnose unit. The number of tetraglycosidic PhEts in nature is very limited.

During our studies, other types of compounds such as lignans and neolignans (57-69) ( $\triangleright$ Fig. 7, Table 7), monomeric phenylpropanoids (70-73) ( $\bullet$ Fig. 8, Table 8 ), quinic acid, and shikimic acid esters (74-76) ( $\triangleright$ Fig.9, Table 9), flavonoids (flavone and flavonol glycosides, methoxyflavones, flavanone) (77-90) ( $\vee$ Fig. 10, Table 10), terpenoids (mono-, di- and triterpenoids) (91-100) ( Fig. 11, Table 11), and miscellaneous metabolites (101-109) ( $\vee$ Fig. 12, Table 12) were also isolated.

\section{Lignans and neolignans (57-69)}

> Table 7.

Monomeric phenylpropanoids (70-73)

- Table 8

Quinic acid and shikimic acid esters (74-76)

- Table 9.

Flavonoids (77-90)

Luteolin and chrysoeriol glycosides (77-86) as flavone derivatives and kaempferol and quercetin glycosides (86-87) as 2 flavonol 


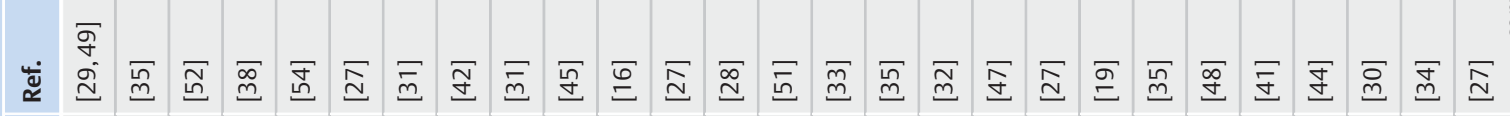
$\bar{\sim}$

오

$\stackrel{9}{-}$

$\stackrel{\infty}{\leftarrow} \times$

乏

$\because$

$\stackrel{\text { ㄴ }}{ } \times$

$\pm$

m

$\simeq \times$

$=x$

우 $\times$

$a$

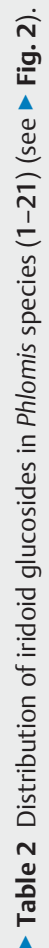

$\infty \times$

N

$6 \times$

in $x$

$\checkmark$

m

N

$-$

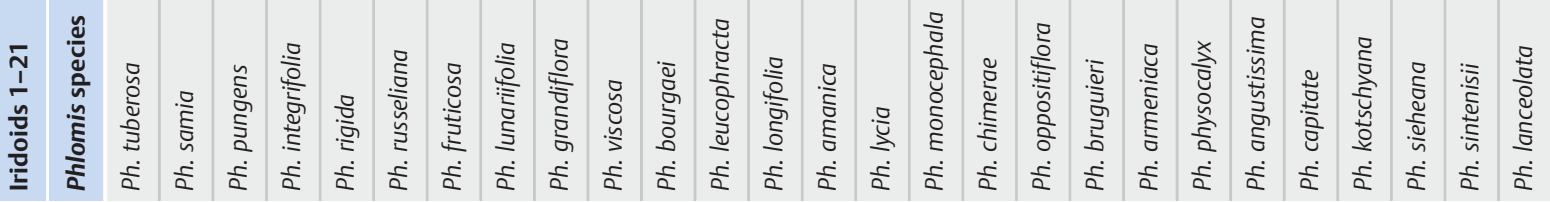




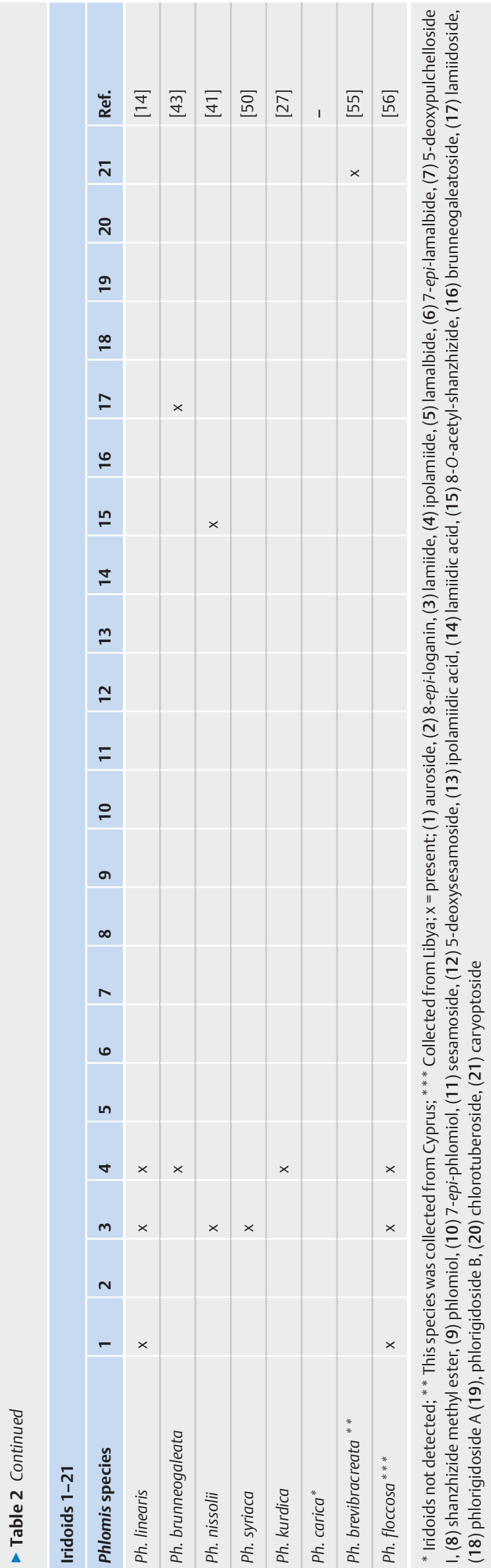

glycosides were isolated in addition to 2 methoxyflavonols (8989 ) and a flavanone, naringenin (90) ( $\bullet$ Fig. 10, Table 10).

\section{Terpenoids (91-100)}

Terpenoids isolated from Phlomis spp are represented by 10 compounds (91-100), and include mono-, di- and triterpenoids ( $\triangleright$ Fig. 11). The monoterpene glycosides betulalbuside A (91) and 1-hydroxylinaloyl 6-O- $\beta$-D-glucopyranoside (92) were isolated from few Phlomis species. Diterpenoids belong to pimarane-type and labdane-type (94-95). Amanicadol (93), a pimarane-type diterpene, was first reported from $P$. amanica [51]. Two labdane-type diterpenes, jhanol (94) and jhanol acetate (95), were isolated from $P$. bourgaei [15]. The most interesting result was the discovery in Ph. viscosa of a novel nortriterpene glycoside, norviscoside (96), that possesses a spirocyclic skeleton and was isolated together with 2 new oleanane-type triterpene glycosides, viscosides A and B $(97,98)[40]$. Two structurally similar nortriterpenoids, (99 and 100) were also isolated from $P$. integrifolia [27].

\section{Further compounds}

Further compounds belonging to different chemical classes ( $\triangleright$ Fig. 12, Table 12) include a megastigmane glycoside (101), 2 acetophenone glycosides (105-106), and an octenol triglycoside (107)

\section{Essential oils}

Phlomis is represented in Turkey by 33 species and altogether 53 taxa. The rate of endemism on a species basis is $48 \%$ and on a taxon basis $57 \%$ [1]. The main components found in the essential oils of Phlomis species growing in Turkey and Northern Cyprus are summarized in > Table 13 [57-75].

Phlomis species are oil-poor. Interestingly, this fact coincides with the occurrence of tricolpate pollen grains, and the essential oils comprise mainly sesquiterpenes, with germacrene $D$ and $\beta$ caryophyllene being the most common constituents ( $\vee$ Fig. 13) [76]. Indeed, within the 36 taxa studied for essential oils, 28 taxa (Ph. amanica, Ph. armeniaca, Ph. bornmuelleri, Ph. bourgaei, Ph. brevibracteata, Ph. bruguieri, Ph. bruneogaleata, Ph. capitata, Ph. chimerae, Ph. cypria, Ph. integrifolia, Ph. kotschyana, Ph. kurdica, Ph. leucophracta, Ph. linearis, Ph. longifolia var. bailanica, Ph. lunariifolia, Ph. lycia, Ph. melitenense, Ph. nissolii, Ph. oppositiflora, Ph. physocalyx, Ph. pungens var. hirta, Ph. pungens var. hispida, Ph. rigida, Ph. russeliana, Ph. samia, Ph. sieheana, Ph. viscosa) contain these 2 sesquiterpene hydrocarbons either singly or together as major constituents.

Other major sesquiterpenes found in Phlomis oils are caryophyllene oxide ( $P$. brevibracteata, $P$. vuralii), (Z)- $\beta$-farnesene ( $P$. bruguieri, $P$. integrifolia, $P$. sieheana), spathulenol ( $P$. sintenisii), $\alpha$-cubebene ( $P$. bourgeai), $\beta$-eudesmol ( $P$. grandiflora var. grandiflora), and $\alpha$-cedrene (P. grandiflora var. grandiflora) ( $\bullet$ Fig. 13).

$P$. viscosa is particularly rich in diterpenes. 8,13-Epoxy-15,16dinorlabd-12-ene, 8,13-epoxy-14-labdene (Manoyl oxide), 8,13epoxy-14-epilabdene (epi-Manoyl oxide), sclareolide, ambrox, and phytol were found in its oil. 8(14),15-Isopimaradien-11 $\alpha$-ol was found as a major constituent in the essential oils of $P$. amanica, P. monocephala, and P. lunariifolia ( $\bullet$ Fig. 14). 

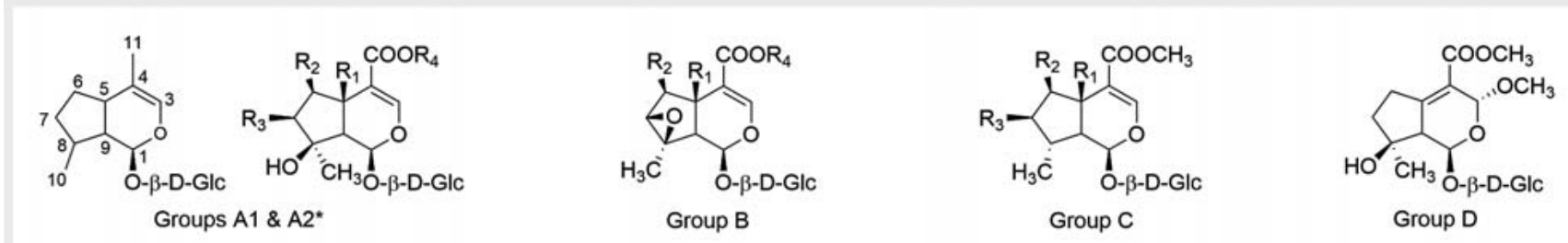

- Fig. 3 Structural types of Phlomis Iridoids. $\mathrm{R}_{1}, \mathrm{R}_{2}$, and $\mathrm{R}_{3}=\mathrm{H}, \mathrm{OH}, \mathrm{Cl}{ }^{*} \mathrm{Group} \mathrm{A}_{1}, \mathrm{R}_{4}=\mathrm{CH}_{3}$; Group $\mathrm{A}_{2}, \mathrm{R}_{4}=\mathrm{H}$.
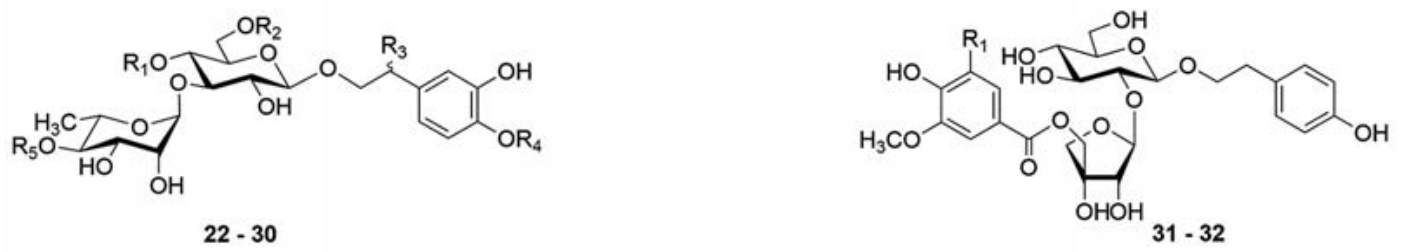

- Fig. 4 Phenylethanoid diglycosides.

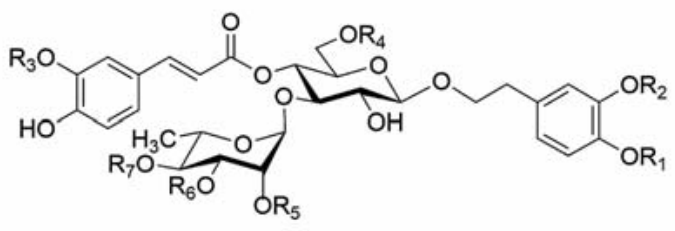

Fig. 5 Tri- and tetraglycosidic phenylethanoids.

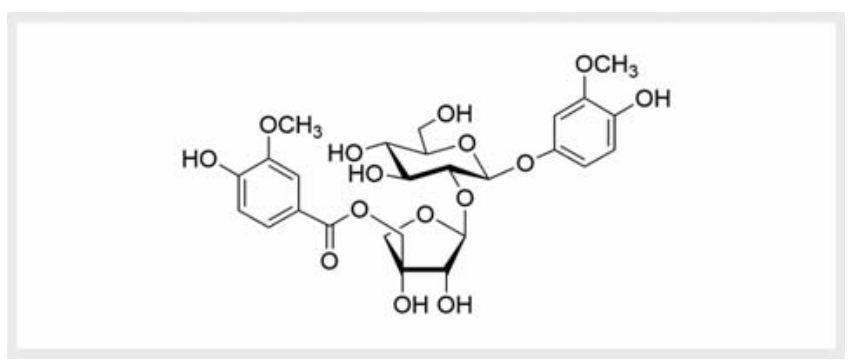

- Fig. 6 Simple phenol glycoside (Group K).

Monoterpenes are rarely found in the essential oils of Phlomis taxa. Limonene (Ph. nissolii), linalool (Ph. leucophracta), and $\alpha$ pinene (Ph. grandiflora var. grandiflora) were detected as the most common monoterpenes.

Among the nonterpenoid volatiles, hexadecanoic acid was found as the main constituent in the oils of Ph. angustissima, Ph. armeniaca, Ph. kotschyana, Ph. bruguieri, Ph. brunneogaleata, Ph. lunariifolia, and Ph. pungens var. pungens.
4-Methoxycarbonyl-7-methylcyclopenta[c]pyran was detected in the oils of Ph. armeniaca (0.2\%) and Ph. sieheana (0.2\%) and characterized using Wiley GC/MS Library peak matching. It was previously reported as a transformation product of ipolamiide (iridoid) after acid hydrolysis and was classified as fulvoiridoid (or pseudoazulene) (• Fig. 15) [77]. 4-Methoxycarbonyl-7-methylcyclopenta[c]pyran was also isolated from Stachytarpheta glabra (Verbenaceae) [78].

\section{Phlomideae}

\section{Eremostachys Bunge}

The genus Eremostachys is closely related to the genus Phlomis. The Irano-Turanian region is the richest zone for this genus with about 60 species [79]. In Turkey, the genus Eremostachys is represented by 3 species: E. moluccelloides, E. laciniata, and E. glabra [26].

\section{Iridoids}

The studies on E. moluccelloides and E. laciniata resulted in the isolation of 14 iridoid glucosides, of which 6 were common for both species. These were lamalbide (5), 5-deoxypulchelloside (7), shanzhizide methyl ester (8), sesamoside (11), 5-deoxysesamoside (phlorogidoside C) (12), and chlorotuberoside (18), [80-81]. Additional iridoids were $6 \beta$-hydroxy-7-epi-loganin (110), lamalbidic acid choline salt (111), 5-deoxy-sesamosidic acid (112), phloyosides I (113), II (114), and shanzhizide (115) (• Fig. 16).

These results suggest that the iridoids of Eremostachys species are structurally related to those of Phlomis with a close similarity of their oxidation pattern. A DNA sequence analysis confirmed the taxonomic relationship between both taxa [82]. 
- Table 3 Phenylethanoid diglycosides (22-32) (see $>$ Fig. 4).

\begin{tabular}{|c|c|c|c|c|c|c|}
\hline & PhEts (Groups A-C) & $\mathbf{R}_{1}$ & $\mathbf{R}_{\mathbf{2}}$ & $\mathbf{R}_{\mathbf{3}}$ & $\mathbf{R}_{\mathbf{4}}$ & $\mathbf{R}_{\mathbf{5}}$ \\
\hline & \multicolumn{6}{|l|}{ Group A } \\
\hline 22 & Decaffeoylacteoside & $\mathrm{H}$ & $\mathrm{H}$ & $\mathrm{H}$ & $\mathrm{H}$ & $\mathrm{H}$ \\
\hline 23 & Verbascoside (= Acteoside) & E-Caffeoyl & $\mathrm{H}$ & $\mathrm{H}$ & $\mathrm{H}$ & $\mathrm{H}$ \\
\hline 24 & cis-Acteoside & Z-Caffeoyl & $\mathrm{H}$ & $\mathrm{H}$ & $\mathrm{H}$ & $\mathrm{H}$ \\
\hline 25 & iso-Acteoside & $\mathrm{H}$ & E-Caffeoyl & $\mathrm{H}$ & $\mathrm{H}$ & $\mathrm{H}$ \\
\hline 26 & Leucosceptoside A & E-Caffeoyl & $\mathrm{H}$ & $\mathrm{H}$ & $\mathrm{CH}_{3}$ & $\mathrm{H}$ \\
\hline 27 & Martynoside & E-Feruloyl & $\mathrm{H}$ & $\mathrm{H}$ & $\mathrm{CH}_{3}$ & $\mathrm{H}$ \\
\hline 28 & iso-Martynoside & $\mathrm{H}$ & E-Feruloyl & $\mathrm{H}$ & $\mathrm{CH}_{3}$ & $\mathrm{H}$ \\
\hline \multirow[t]{2}{*}{29} & 4"-O-acetylmartynoside & E-Feruloyl & $\mathrm{H}$ & $\mathrm{H}$ & $\mathrm{CH}_{3}$ & $\mathrm{COCH}_{3}$ \\
\hline & \multicolumn{6}{|l|}{ Group B } \\
\hline \multirow[t]{2}{*}{30} & $\beta$-hydroxyacteoside & E-Caffeoyl & $\mathrm{H}$ & $\mathrm{OH}$ & $\mathrm{H}$ & $\mathrm{H}$ \\
\hline & \multicolumn{6}{|l|}{ Group C } \\
\hline 31 & Hattuschoside & $\mathrm{OCH}_{3}$ & & & & \\
\hline 32 & Fimbrilloside (= Phlomisethanoside) & $\mathrm{H}$ & & & & \\
\hline
\end{tabular}

\section{Phenylethanoid glycosides}

The studies on E. laciniata resulted in the isolation of di- and triglycosidic phenylethanoid glycosides, including verbascoside (23), leucosceptoside A (26), martynoside (27), and forsythoside B (33) [81].

\section{Bioactivity Studies}

Bioactivity studies were mostly performed with isolated compounds. Earlier studies focused on phenylethanoid glycosides. In 1994, the structures of more than 150 phenylethanoid glycosides and their biological activities were discussed in detail [83]. This review summarized the methods for isolation, purification, structure elucidation and biological activities, biogenesis, and taxonomy of the PhEts. Acteoside (=verbascoside) is one of the major PhEts isolated from medicinal plants, and many further PhEts have been widely investigated for their inhibitory activities on enzymes such as aldose reductase, 5-lipoxygenase, protein kinase $C$, and CAMP-phosphodiesterase and on 5-HETE (5-hydroxyeicosatetraenoic acid) formation. In addition, antibacterial, cytotoxic, antioxidant, antihepatotoxic, antihypertensive, analgesic, sedative, antitremor L-DOPA, and immunosuppressant activities, as well as protective activity against a decrease of libido and learning behaviors in mice, have been described. In 1995, acteoside (23), leucosceptoside $A(26)$, martynoside (27), forsythoside $B(33)$, phlinosides $B$ (48) and C (51), and teucrioside (53) as well as an iridoid glucoside, ipolamiide (4), isolated from Ph. armeniaca have been investigated for cytotoxic and cytostatic activities by the MTT method against dRLh-88 (rat hepatoma), HeLa, P-388-D1 (mouse lymphoid neoplasm), and S-180 (sarcoma) cell lines [19]. PhEts with a caffeoyl moiety as ester functionality were reported to show activity against several types of cancer cells. Structure-activity rela- tionships revealed the importance of the presence of ortho-dihydroxy aryl units in PhEts. Thus, 23, 33, and 53 were reported to show stronger activity compared to methoxylated PhEts such as 26 and 27. As a continuation of these studies, 4 more PhEts, angorosides A, B, and C isolated from Scrophularia scopolii $[7,8]$ and poliumoside from Teucrium polium and a lignan, (+)-syringaresinol 0 - $\beta$-D-glucopyranoside (66), from Scutellaria albida subsp. colchica were investigated for cytotoxic and cytostatic activities [84]. No activity was observed for methylated derivatives such as angorosides $B$ and $C$. The caffeic acid-containing PhEts angoroside $A$ and poliumoside, as well as (+)-syringaresinol $O-\beta$-D-glucopyranoside (66), were found to exhibit significant cytotoxic activity against dRLh-84, HeLa, S-180, and P388/D1 cells. No cytotoxic effects against primary-cultured rat hepatocytes were observed for PhEts [84]. In 2000, a series of 21 PhEts were tested for radical scavenging activity by quantifying their effects on the production of reactive oxygen species (ROS) in a luminol-enhanced chemiluminescence assay with formyl-methionine-leucyl-phenylalanine (FMPL)-stimulated human polymorphonuclear neutrophils (PMNs) [19]. The compounds used in this study were isolated from Lamiaceae (Phlomis, Galeopsis, Marrubium, Scutellaria species), Globulariaceae (Globularia sp.), and Scrophulariaceae (Pedicularis and Digitalis sp.). They possessed mono-, di- and triglycosidic structures and include some deacyl derivatives. PhEts acylated with phenolic acids were found to show stronger activity whereas the deacyl derivatives were more than 30 -fold less active. The potency of the antioxidant activity was mainly depending on the number of phenolic hydroxyl or methoxyl groups. The sugar type and the position of the glycosidic bonds, as well as the sugar sequence, seemed to have no effect on the activity [85]. Forty-eight PhEts isolated not only from Lamiaceae plants but also from Scrophulariaceae, Globulariaceae, and Oleaceae plants were reviewed 
- Table 4 Tri- and tetraglycosidic phenylethanoids (33-55) (see $>$ Fig. 5).

\begin{tabular}{|c|c|c|c|c|c|c|c|c|}
\hline & & \multicolumn{2}{|c|}{ Phenethylalcohol } & \multirow{2}{*}{$\begin{array}{l}\text { Acyl } \\
R_{3}\end{array}$} & \multirow{2}{*}{$\begin{array}{l}\text { Glucosyl } \\
\mathbf{R}_{\mathbf{4}}\end{array}$} & \multicolumn{3}{|c|}{ Rhamnosyl } \\
\hline & & $\mathbf{R}_{1}$ & $\mathbf{R}_{\mathbf{2}}$ & & & $\mathbf{R}_{5}$ & $\mathbf{R}_{6}$ & $\mathbf{R}_{7}$ \\
\hline & \multicolumn{8}{|l|}{ Triglycosidic PhEts } \\
\hline & \multicolumn{8}{|l|}{ Group D } \\
\hline 33 & Forythoside B & $\mathrm{H}$ & $\mathrm{H}$ & $\mathrm{H}$ & Api & $\mathrm{H}$ & $\mathrm{H}$ & $\mathrm{H}$ \\
\hline 34 & Alyssonoside & $\mathrm{H}$ & $\mathrm{H}$ & $\mathrm{CH}_{3}$ & Api & $\mathrm{H}$ & $\mathrm{H}$ & $\mathrm{H}$ \\
\hline 35 & Leucosceptoside B & $\mathrm{CH}_{3}$ & $\mathrm{H}$ & $\mathrm{CH}_{3}$ & Api & $\mathrm{H}$ & $\mathrm{H}$ & $\mathrm{H}$ \\
\hline \multirow[t]{2}{*}{36} & Lamiophlomoside A & $\mathrm{H}$ & $\mathrm{CH}_{3}$ & $\mathrm{CH}_{3}$ & Api & $\mathrm{H}$ & $\mathrm{H}$ & $\mathrm{H}$ \\
\hline & \multicolumn{8}{|l|}{ Group $E$} \\
\hline 37 & Samioside & $\mathrm{H}$ & $\mathrm{H}$ & $\mathrm{H}$ & $\mathrm{H}$ & $\mathrm{H}$ & $\mathrm{H}$ & Api \\
\hline 38 & Integrifolioside A & $\mathrm{H}$ & $\mathrm{H}$ & $\mathrm{CH}_{3}$ & $\mathrm{H}$ & $\mathrm{H}$ & $\mathrm{H}$ & Api \\
\hline \multirow[t]{2}{*}{39} & Integrifolioside B & $\mathrm{CH}_{3}$ & $\mathrm{H}$ & $\mathrm{CH}_{3}$ & $\mathrm{H}$ & $\mathrm{H}$ & $\mathrm{H}$ & Api \\
\hline & \multicolumn{8}{|l|}{ Group F } \\
\hline 40 & Myricoside & $\mathrm{H}$ & $\mathrm{H}$ & $\mathrm{H}$ & $\mathrm{H}$ & $\mathrm{H}$ & Api & $\mathrm{H}$ \\
\hline 41 & Oppositifloroside & $\mathrm{H}$ & $\mathrm{H}$ & $\mathrm{CH}_{3}$ & $\mathrm{H}$ & $\mathrm{H}$ & Api & $\mathrm{H}$ \\
\hline \multirow[t]{2}{*}{42} & Serratumoside & $\mathrm{CH}_{3}$ & $\mathrm{H}$ & $\mathrm{CH}_{3}$ & $\mathrm{H}$ & $\mathrm{H}$ & Api & $\mathrm{H}$ \\
\hline & \multicolumn{8}{|l|}{ Group $G_{1}$} \\
\hline 43 & Echinacoside & $\mathrm{H}$ & $\mathrm{H}$ & $\mathrm{H}$ & Glc & $\mathrm{H}$ & $\mathrm{H}$ & $\mathrm{H}$ \\
\hline 44 & Glucopyranosyl-( $\left(1 \rightarrow G_{i}-6^{\prime}\right)$-martynoside & $\mathrm{CH}_{3}$ & $\mathrm{H}$ & $\mathrm{CH}_{3}$ & Glc & $\mathrm{H}$ & $\mathrm{H}$ & $\mathrm{H}$ \\
\hline \multirow[t]{2}{*}{45} & Wiedemannioside C & $\mathrm{H}$ & $\mathrm{H}$ & $\mathrm{CH}_{3}$ & Glc & $\mathrm{H}$ & $\mathrm{H}$ & $\mathrm{H}$ \\
\hline & \multicolumn{8}{|l|}{ Group $G_{2}$} \\
\hline \multirow[t]{2}{*}{46} & Arenarioside & $\mathrm{H}$ & $\mathrm{H}$ & $\mathrm{H}$ & Xyl & $\mathrm{H}$ & $\mathrm{H}$ & $\mathrm{H}$ \\
\hline & \multicolumn{8}{|l|}{ Group $H_{1}$} \\
\hline \multirow[t]{2}{*}{47} & Phlinoside A & $\mathrm{H}$ & $\mathrm{H}$ & $\mathrm{H}$ & $\mathrm{H}$ & Glc & $\mathrm{H}$ & $\mathrm{H}$ \\
\hline & \multicolumn{8}{|l|}{ Group $\mathrm{H}_{2}$} \\
\hline 48 & Phlinoside B & $\mathrm{H}$ & $\mathrm{H}$ & $\mathrm{H}$ & & Xyl & $\mathrm{H}$ & $\mathrm{H}$ \\
\hline 49 & Phlinoside D & $\mathrm{H}$ & $\mathrm{H}$ & $\mathrm{CH}_{3}$ & & Xyl & $\mathrm{H}$ & $\mathrm{H}$ \\
\hline \multirow[t]{2}{*}{50} & Phlinoside F & $\mathrm{CH}_{3}$ & $\mathrm{H}$ & $\mathrm{CH}_{3}$ & & Xyl & $\mathrm{H}$ & $\mathrm{H}$ \\
\hline & \multicolumn{8}{|l|}{ Group $\mathrm{H}_{3}$} \\
\hline 51 & Phlinoside C & $\mathrm{H}$ & $\mathrm{H}$ & $\mathrm{H}$ & & Rha & $\mathrm{H}$ & $\mathrm{H}$ \\
\hline \multirow[t]{2}{*}{52} & Phlinoside E & $\mathrm{CH}_{3}$ & $\mathrm{H}$ & $\mathrm{H}$ & & Rha & $\mathrm{H}$ & $\mathrm{H}$ \\
\hline & \multicolumn{8}{|l|}{ Group $\mathrm{H}_{4}$} \\
\hline \multirow[t]{3}{*}{53} & Teucrioside & $\mathrm{H}$ & $\mathrm{H}$ & $\mathrm{H}$ & & Lyx & $\mathrm{H}$ & $\mathrm{H}$ \\
\hline & \multicolumn{8}{|l|}{ Tetraglycosidic PhEts } \\
\hline & \multicolumn{8}{|l|}{ Group I } \\
\hline \multirow[t]{2}{*}{54} & Physocalycoside & $\mathrm{H}$ & $\mathrm{H}$ & $\mathrm{H}$ & Glc & Rha & $\mathrm{H}$ & $\mathrm{H}$ \\
\hline & Group J & & & & & & & \\
\hline 55 & Lunarifolioside & $\mathrm{H}$ & $\mathrm{H}$ & $\mathrm{H}$ & Api & $\mathrm{H}$ & $\mathrm{H}$ & Api \\
\hline
\end{tabular}


- Table 5 Phenylethanoid glycosides grouped according to glycosidation patterns (22-56).

\begin{tabular}{|l|l}
\hline \begin{tabular}{l} 
Phenylethanoid Glycosides (Groups A-K) \\
\hline - Diglycosides
\end{tabular} \\
\hline Group A & - (22) Decaffeoylacteoside \\
& $=(23)$ Verbascoside (=Acteoside) \\
& $=(24)$ cis-Acteoside \\
& $=(25)$ iso-Acteoside \\
& $=(26)$ Leuceptoside A \\
& $=(27)$ Martynoside \\
& $=(28)$ iso-Martynoside \\
& $=(29) 4$-O-acetyl-martynoside \\
\hline Group B & - (30) $\beta$-hydroxyacteoside \\
\hline Group C & - (31) Hattushoside \\
\hline
\end{tabular}

\begin{tabular}{|c|c|}
\hline \multicolumn{2}{|c|}{ Triglycosides } \\
\hline Group D & $\begin{array}{l}\text { - (33) Forsythoside B } \\
\text { - (34) Alyssonoside } \\
\text { - (35) Leuceptoside B } \\
\text { - (36) Lamiophlomoside A }\end{array}$ \\
\hline Group E & $\begin{array}{l}\text { - (37) Samioside } \\
\text { - (38) Integrifolioside A } \\
\text { - (39) Integrifolioside B }\end{array}$ \\
\hline Group F & $\begin{array}{l}\text { (40) Myricoside } \\
\text { - }(41) \text { Oppositifloroside } \\
\text { - }(42) \text { Serratumoside }\end{array}$ \\
\hline Group $G_{1}$ & $\begin{array}{l}\text { - (43) Echinacoside } \\
\text { - (44) Glucopyranosyl-( }(\rightarrow 6) \text {-martyno- } \\
\text { side } \\
\text { - (45) Videmannioside C }\end{array}$ \\
\hline Group $G_{2}$ & - (46) Arenarioside \\
\hline Group $\mathrm{H}_{1}$ & - (47) Phlinoside A \\
\hline Group $\mathrm{H}_{2}$ & $\begin{array}{l}\text { - (48) Phlinoside B } \\
\text { - (49) Phlinoside D } \\
\text { - (50) Phlinoside F }\end{array}$ \\
\hline Group $\mathrm{H}_{3}$ & $\begin{array}{l}\text { - (51) Phlinoside C } \\
\text { - (52) Phlinoside E }\end{array}$ \\
\hline Group $\mathrm{H}_{4}$ & - (53) Teucrioside \\
\hline \multicolumn{2}{|c|}{ Tetraglycosides } \\
\hline Group I & - (54) Physocalycoside \\
\hline Group J & - (55) Lunarifolioside \\
\hline \multicolumn{2}{|c|}{ Simple phenol glycoside = Hydroquinone glycoside } \\
\hline Group K & - (56) Seguinoside K (= Phloviscoside) \\
\hline
\end{tabular}

concerning their structural diversity and biological activities studied in house or in collaborative settings [86]. Regardless of the plant from which it was isolated, acteoside (22) has been the most studied compound among the PhEts. Acteoside-induced apoptosis in HL-60 cells [87]. Moreover, these studies suggest that acteoside possesses a selectivity in its cytotoxic activity between normal cells and cancer cells. It was proposed that the activity of acteoside depends mainly on the redox state in cells. Moreover, antimetastatic activity examined on lung metastasis using a mouse model with B16 melanoma cells has shown a suppressive effect of acteoside (23) [88]. Four PhEts glycosideslavandulifolioside, acteoside (23), leucosceptoside A (26), and martynoside (27)-isolated from aerial parts of Sideritis lycia (Lamiaceae) have been investigated for their anti-inflammatory activity together with flavonoid glycosides isolated from the same plant [89]. Lavandulifolioside is a triglycosidic phenylethanoid glycoside, which can be classified in the group $\mathrm{H}$ and was first isolated from Stachys lavandulifolia [11]. In this study, the flavonoid glycosides showed higher activity than PhEts. However, the gastric ulceration effect of PhEts was found to be less than that of flavonoid glycosides [89]. Acteoside and an iridoid, 1,5,9-epi-deoxyloganic acid, isolated from Nepeta ucrainica (Subfamily: Nepetoideae) have been investigated for immunomodulatory activity [90]. Acteoside showed a positive chemotactic activity at all doses, and the intracellular killing activity of neutrophils did not change significantly. On the other hand, the decreasing values observed with higher doses point to possible immunosuppresive and antioxidant effects.

In vitro effects of acteoside (23) and forsythoside B (33) together with isoorientin have been investigated on purified bovine kidney cortex GR. Both compounds inhibited bovine kidney cortex GR in a concentration-dependent manner. Forsythoside B and acteoside were found to act as an uncompetitive inhibitor of GR, which causes accumulation of reactive oxygen species and depletion of the glutathione pool. It has been assumed that the inhibition of GR might be significant in drug resistance [91].

Due to the high number of constituents and the richest chemical diversity of the structures isolated, metabolites from $P$. brunneogaleata and $P$. viscosa were submitted to an activity screening panel $[43,45]$.

Inhibitory activities of 16 compounds belonging to different chemical groups isolated from $P$. brunneogaleata were tested against parasitic protozoa (Plasmodium falciparum, Trypanosoma cruzi, T. brucei, Leishmania donovani) and plasmodial enoyl-ACP reductase [43]. These compounds include 2 iridoids, ipolamiid (4) and brunneogaleatoside (16); 6 PhEts, verbascoside (23), isoverbascoside (24), forsythoside B (33), echinacoside (43), integrifolioside B (39), glucopyranosyl-( $\left.\rightarrow G_{i}-6\right)$-martynoside (44); a lignan, liriodendrin (67); 3 caffeic acid esters, chlorogenic acid (74), 3-O-caffeoyl-quinic acid (75), and 5-O-caffeoyl-shikimic acid (76); 2 flavone glycosides, luteolin 7-O- $\beta$-D-glucopyranoside (77) and chrysoeriol 7-O- $\beta$-D-glucopyranoside (82); an acetophenone glycoside, 4-hydroxyacetophenone 4-O-(6'-O- $\beta$-D-apiofuranosyl)- $\beta$ D-glucopyranoside (105); and (2R,4S)-2-carboxy-4-(E)-p-coumaroyloxy-1,1-dimethylpyrolidinium inner salt (102). Flavone derivatives 77 and 82 were found to possess the highest antimalarial activity among the tested metabolites. Both compounds also exhibited substantial leishmanicidal activity, and 77 displayed strong enzyme inhibitory potential toward plasmodial Fabl enzyme [43].

The studies on $P$. viscosa resulted in the isolation of a total 27 compounds, comprising 2 oleanan-type triterpene saponins, 


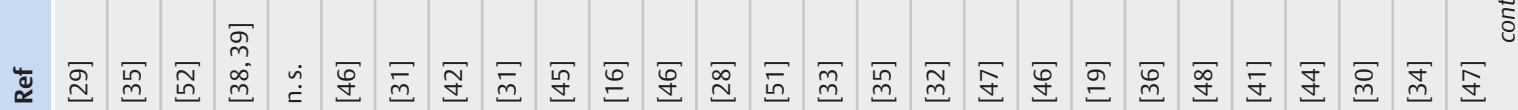

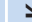
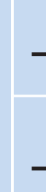

I
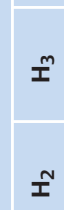

$\bar{I}$

$\checkmark$

$\checkmark$

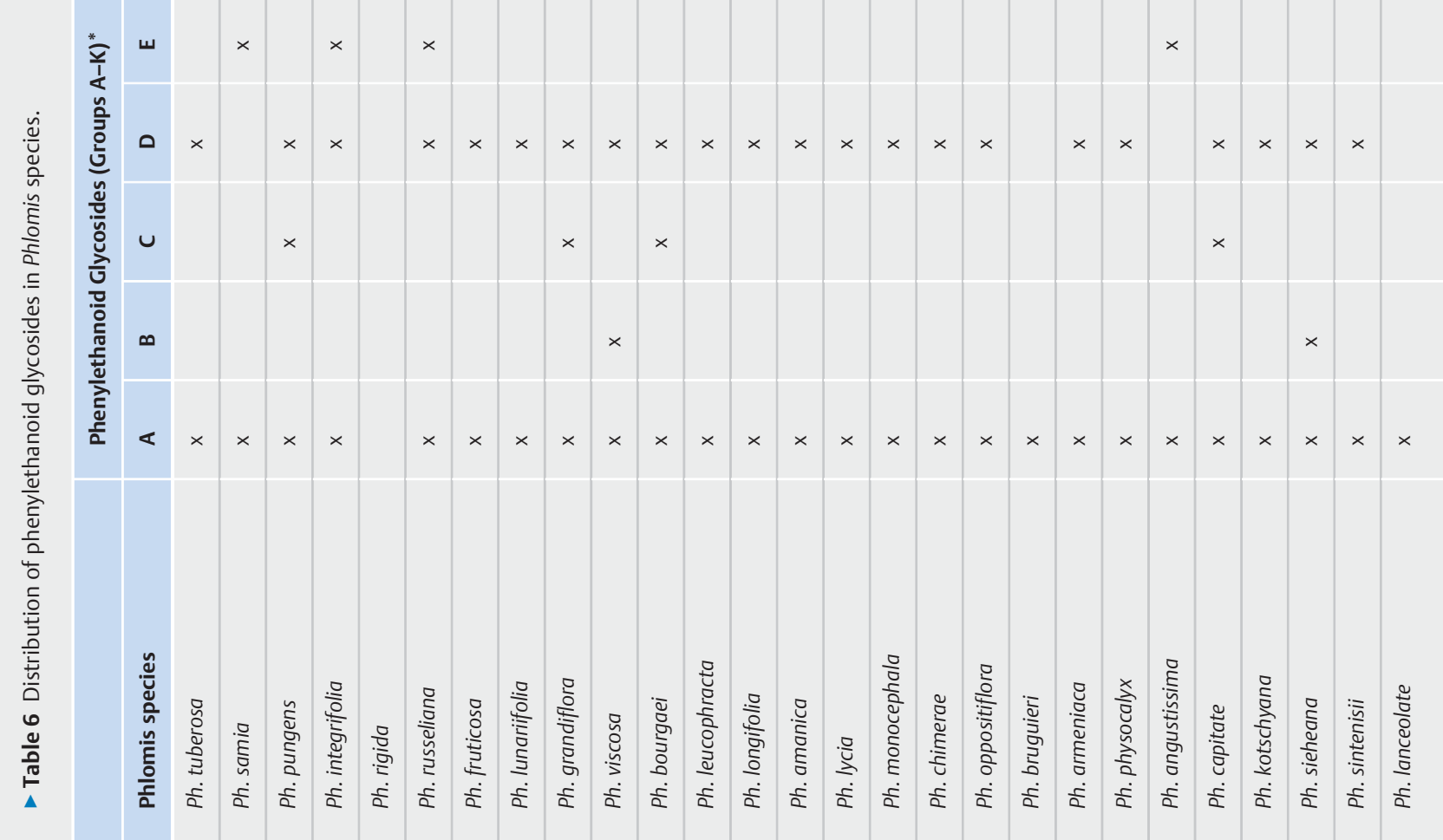




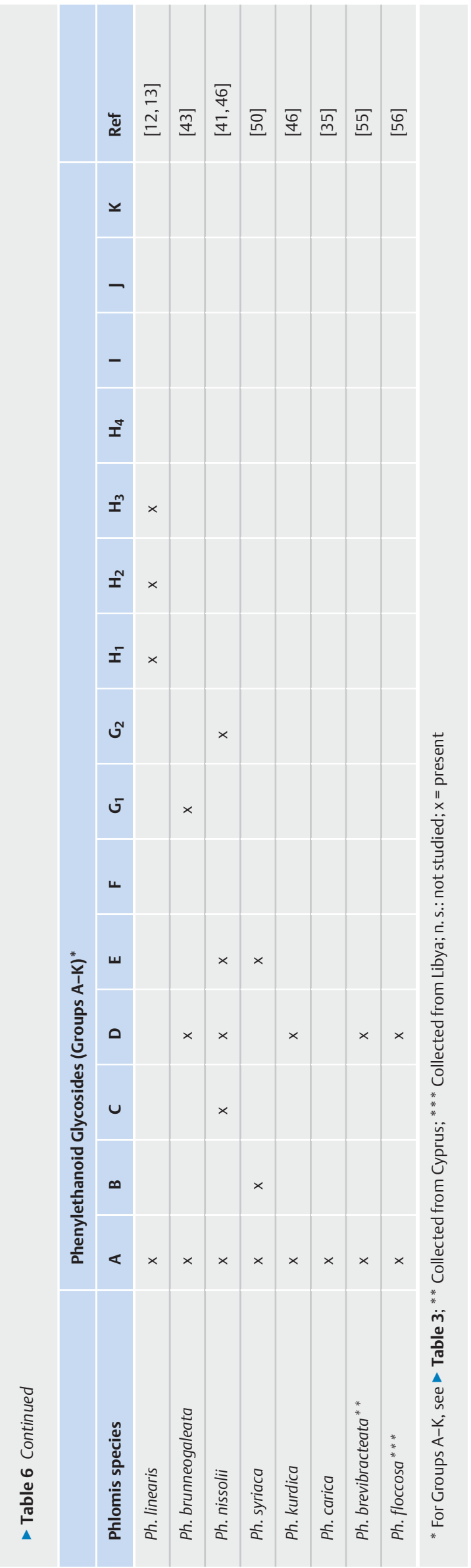

1 nortriterpene [40], 3 iridoids, 10 PhETs, 1 megastigmane glycoside, 2 lignans, 7 neolignans, and 1 hydroquinone glycoside [45]. The isolated compounds included the iridoids: ipolamiide (3), lamiide (4) and lamiidoside (17); the PhEts: decaffeoyl-acteoside (22), verbascoside (23), isoacteoside (25), leucosceptoside $A$ (26), martynoside (27), $\beta$-hydroxyacteoside (30), forsythoside $B$ (33), alyssonoside (34), leucosceptoside B (35), and myricoside (40); a hydroquinone glycoside: seguinoside $\mathrm{K}(56)$; the neolignan glucosides: dihydrodehydrodiconiferylalcohol 4-O- $\beta$-glucopyranoside (57), a mixture of dihydrodehydro-diconiferylalcohol 9-0$\beta$-glucopyranoside (58) and dihydrodehydrodiconiferylalcohol 9'$O-\beta$-glucopyranoside (59); (-)-4-O-methyl-dihydrodehydrodiconiferyl alcohol 9'-O- $\beta$-D-glucopyranoside (60); (-)-4-O-methyl-dihydrodehydrodiconiferyl alcohol 9-O- $\beta$-D-glucopyranoside (61); dehydrodiconiferyl-alcohol 9'-O- $\beta$-glucopyranoside (63); 8-O-4' neolignan 4-O- $\beta$-glucopyranoside (= erythro-1-(4-O- $\beta$-glucopyranosyl-3-methoxyphenyl)-2-\{2-methoxyl-4-[1-(E)-propen-3-ol]phenoxyl\}-propan-1,3-diol) (69); the lignan glucosides: syringaresinol 4'-O- $\beta$-glucopyranoside (66) and lariciresinol 4-O- $\beta$-glucopyranoside (68) and a megastigmane glycoside: phlomuroside (101). Samioside (37) isolated from P. samia [35] was also added to the activity screenings.

The metabolites from $P$. viscosa were tested for radical scavenging, antibacterial and antifungal activities, and cell growth inhibition. All the compounds were also evaluated for cell growth inhibition versus 3 cell lines (MCF 7, NCl-H460, and SF-268) in the $\mathrm{NCl}$ cancer prescreen panel. Iridoids were not active. In contrast, PhEts 23, 25, 33, 34, 37, and 40 were found to reduce the growth of at least 1 cell line to $<32 \%$ of the control (dl-a-tocopherol) and were further subjected to the full 60-cell line panel. However, the concentrations required to inhibit cell growth at the GI-50 level were greater than $47 \mu \mathrm{M}$ in all cases, with minimal differential inhibition among the cell lines. Thus, these compounds were not investigated further as inhibitors of cancer cell growth. Compounds $23,25,33,37$, and 40 were found to be free radical scavengers with activity comparable to $\mathrm{dl}$ - $\alpha$-tocopherol. Compounds 23, 25, 33, and 37 exhibited weak activity against Gram (+) bacteria [45]. The antioxidative activity of the PhEts was in line with an earlier study [84]. In one of the ongoing studies on Phlomis species, the protective effect of the PhEts from $P$. pungens against free radicalinduced functional endothelial injury was found to correlate with the free radical scavenging activity arising from the phenolic hydroxyl groups [91].

The potential inhibitory effect of verbascoside (= acteoside) (23) on neurotoxicity has been studied, and the compound has been suggested to be useful in the treatment of neurological diseases such as parkinsonism [92]. The recent studies have focused on the chemistry, pharmacological activity, and pharmacokinetics of PhEts [93-95]. Verbascoside (= acteoside) (23), as a widely distributed PhEt in the plant kingdom, has been discussed in many perspectives, including biosynthesis, production using biotechnological methods and pharmacological activities, molecular features, and principal photoprotective activities in human keratinocytes [93]. The presence of PhETs in many medicinal plants and the diversity in their structure and biological activity have been a point of attraction for scientists. In 2016, Xue and Yang reviewed the biological activities such as neuroprotective, anti-inflamma- 


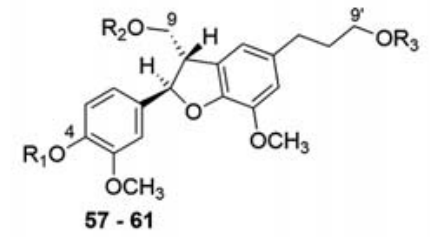<smiles>[R6]Oc1c(OC)cc([C@H]2OC[C@H]3[C@@H](c4cc(O)c([R20])c(OC)c4)OC[C@@H]23)cc1OC</smiles>

$66-67$<smiles>[R6]OCC=Cc1cc(OC)c2c(c1)[C@H](CO[R20])[C@H](c1ccc([R6])c(OC)c1)O2</smiles><smiles>COc1cc([C@@H]2[C@@H](CO)OC[C@H]2c2ccc(OC(O)C(O)CO)c(OC)c2)ccc1O</smiles>

68<smiles>[R6]Oc1ccc([C@@H]2Oc3c(OC)cc(/C=C/C=O)cc3[C@@H]2CO)cc1OC</smiles>

65

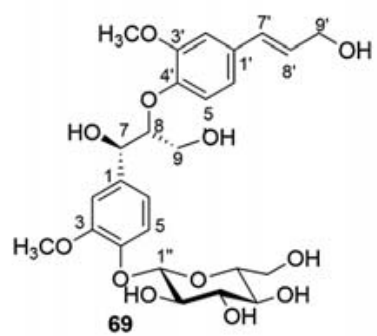

- Fig. 7 Lignan and neolignans from Phlomis species.

- Table 7 Lignans and neolignans from Phlomis species (57-69) (see $>$ Fig. 7).

\begin{tabular}{|c|c|c|c|}
\hline & Lignan and neolignans glycosides (57-69) & Phlomis species & Refs \\
\hline 57 & $\begin{array}{l}\text { Dihydrodehydrodiconiferyl alcohol 4-O- } \beta \text {-D-glucopyranoside } \\
\mathrm{R}_{1}=\mathrm{Glc} ; \mathrm{R}_{2}=\mathrm{H} ; \mathrm{R}_{3}=\mathrm{H}\end{array}$ & $\begin{array}{l}\text { Ph. lycia } \\
\text { Ph. viscosa }\end{array}$ & $\begin{array}{l}{[33]} \\
{[45]}\end{array}$ \\
\hline 58 & $\begin{array}{l}\text { Dihydrodehydrodiconiferyl alcohol 9-O- } \beta \text {-D-glucopyranoside } \\
\mathrm{R}_{1}=\mathrm{H} ; \mathrm{R}_{2}=\mathrm{Glc} ; \mathrm{R}_{3}=\mathrm{H}\end{array}$ & $\begin{array}{l}\text { Ph. chimerae } \\
\text { Ph. lunariifolia } \\
\text { Ph. viscosa }\end{array}$ & $\begin{array}{l}{[33]} \\
{[42]} \\
{[45]}\end{array}$ \\
\hline 59 & $\begin{array}{l}\text { Dihydrodehydrodiconiferyl alcohol 9'-O- } \beta \text {-D-glucopyranoside } \\
\mathrm{R}_{1}=\mathrm{H} ; \mathrm{R}_{2}=\mathrm{H} ; \mathrm{R}_{3}=\mathrm{Glc}\end{array}$ & $\begin{array}{l}\text { Ph. lunarifolia } \\
\text { Ph. viscosa }\end{array}$ & [42] \\
\hline 60 & $\begin{array}{l}(-)-4-O \text {-methyldihydrodehydrodiconiferyl alcohol 9'-O- } \beta \text {-D-glucopyranoside } \\
\mathrm{R}_{1}=\mathrm{CH}_{3} ; \mathrm{R}_{2}=\mathrm{H} ; \mathrm{R}_{3}=\mathrm{Glc}\end{array}$ & $\begin{array}{l}\text { Ph. chimerae } \\
\text { Ph. viscosa }\end{array}$ & $\begin{array}{l}{[32]} \\
{[45]}\end{array}$ \\
\hline 61 & 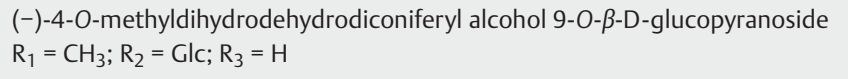 & Ph. viscosa & [45] \\
\hline 62 & $\begin{array}{l}\text { Dehydrodiconiferyl alcohol 4-O- } \beta \text {-D-glucopyranoside } \\
\mathrm{R}_{1}=\mathrm{Glc} ; \mathrm{R}_{2}=\mathrm{H} ; \mathrm{R}_{3}=\mathrm{H}\end{array}$ & Ph. integrifolia & [38] \\
\hline 63 & $\begin{array}{l}\text { Dehydrodiconiferyl alcohol 9'-O- } \beta \text {-D-glucopyranoside } \\
\mathrm{R}_{1}=\mathrm{H} ; \mathrm{R}_{2}=\mathrm{H} ; \mathrm{R}_{3}=\mathrm{Glc}\end{array}$ & Ph. viscosa & [45] \\
\hline 64 & $\begin{array}{l}(-)-4-O \text {-methyldehydrodiconiferyl alcohol 9'-O- } \beta \text {-D-glucopyranoside } \\
\mathrm{R}_{1}=\mathrm{CH}_{3} ; \mathrm{R}_{2}=\mathrm{H} ; \mathrm{R}_{3}=\mathrm{Glc}\end{array}$ & Ph. chimera & [32] \\
\hline 65 & $\begin{array}{l}(7 S, 8 R) \text {-dehydroconiferyl alcohol-8-5'-dehydroconiferylaldehyde-4-O- } \beta \text {-D- } \\
\text { glucopyranoside }\end{array}$ & Ph. oppositiflora & [47] \\
\hline 66 & $\begin{array}{l}\text { Syringaresinol-4'-O- } \beta \text {-D-glucopyranoside } \\
\mathrm{R}=\mathrm{H}\end{array}$ & $\begin{array}{l}\text { Ph. grandiflora var. fimbrilligera } \\
\text { Ph. monocephala }\end{array}$ & [35] \\
\hline 67 & $\begin{array}{l}\text { Liriodendrin } \\
\mathrm{R}=\beta \text {-D-glc }\end{array}$ & $\begin{array}{l}\text { Ph. kotschyana } \\
\text { Ph. capitata } \\
\text { Ph. brunneogaleata }\end{array}$ & [44] \\
\hline 68 & Lariciresinol 4-O- $\beta$-glucopyranoside & Ph. viscosa & [45] \\
\hline 69 & $\begin{array}{l}\text { 8-O-4' neolignan 4-O- } \beta \text {-glucopyranoside (= erythro-1-(4-O- } \beta \text {-glucopyrano- } \\
\text { syl-3-methoxyphenyl)-2-\{2-methoxyl-4-[1-(E)-propen-3-ol]-phenoxyl\}- } \\
\text { propan-1,3-diol) }\end{array}$ & Ph. viscosa & [45] \\
\hline
\end{tabular}


<smiles>[R1]OC=Cc1cc([R2])c([R6])c(OC)c1</smiles>

$70-72$

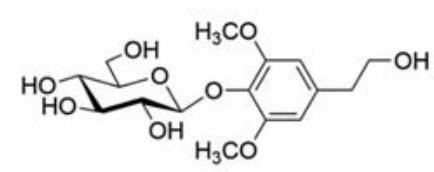

73

Fig. 8 Monomeric phenylpropanoids from Phlomis species.<smiles>[R]OC(=O)C1(O)C[C@H](O)[C@H](O)[C@H](OC(=O)/C=C/c2ccc(O)c(O)c2)C1</smiles>

$74-75$<smiles>O=C(/C=C/c1ccc(O)c(O)c1)OC1CC(C(=O)O)=C[C@H](O)[C@@H]1O</smiles>

76

- Table 8 Monomeric phenylpropanoids from Phlomis species (70-73) (see \ Fig. 8).

\begin{tabular}{|l|l|l|l|}
\hline & Monomeric phenylpropanoids & Phlomis species & Refs \\
\hline 70 & Syringin, $\mathrm{R}_{1}=\mathrm{H}, \mathrm{R}_{2}=\mathrm{OCH}_{3}, \mathrm{R}_{3}=\beta$-glc & Ph. chimerae & Ph. carica \\
\hline & & Ph. carica \\
\hline 71 & Coniferin, $\mathrm{R}_{1}=\mathrm{R}_{2}=\mathrm{H}, \mathrm{R}_{3}=\beta$-glc & Ph. amanica \\
\hline 72 & $\begin{array}{l}\text { 3,5-Dimethoxy-4-hydroxycinnamoyl alcohol 9-O- } \beta \text {-glucopyranoside } \\
\mathrm{R}_{1}=\beta \text {-glc, } \mathrm{R}_{2}=\mathrm{OCH}_{3}, \mathrm{R}_{3}=\mathrm{H}\end{array}$ & \\
\hline $\mathbf{7 3}$ & Dihydrosyringin & Ph. carica \\
\hline
\end{tabular}

- Table 9 Quinic acid and shikimic acid esters (74-76) (see $>$ Fig. 9).

\begin{tabular}{|l|l|l|l|}
\hline & Quinic acid and shikimic acid esters & Phlomis species & Refs \\
\hline $\mathbf{7 4}$ & Chlorogenic acid, $\mathrm{R}=\mathrm{H}$ & All Phlomis spp. & [27] \\
\hline $\mathbf{7 5}$ & Caffeoylquinic acid methyl ester, $\mathrm{R}=\mathrm{CH}_{3}$ & Ph. brunneogaleata \\
\hline 76 & 5-O-Caffeoyl-shikimic acid & Ph. brunneogaleata & {$[43]$} \\
\hline
\end{tabular}<smiles>[R2]Oc1cc(-c2cc(=O)c3c(O)cc(O)cc3o2)ccc1O</smiles>

Fig. 10 Flavonoids.

Fig. 9 Quinic acid and shikimic acid esters.

tory, antioxidant, antibacterial and antiviral, cytotoxic, immunomodulatory properties, and enzyme inhibitory effects, as well as pharmacokinetic properties of the new PhEts isolated between 2005 and 2015 [94]. A recent review reported the structures of 375 PhEts including 57 mono-, 143 di-, 161 tri-, and 14 tetraglycosidic structures, their plant sources, biosynthesis, and chemical synthesis together with their pharmacological activities in a wider perspective [95].

Finally, some Phlomis oils have been tested for various biological activities. The following activities were detected: Antibacterial: Ph. grandiflora [68], Ph. russeliana [68]; anticandidal (Ph. amanica [58], Ph. armeniaca [58], Ph. Iunariifolia [58], 
- Table 10 Flavonoids isolated from Phlomis species (77-90) (see $>$ Fig. 10).

\begin{tabular}{|c|c|c|c|}
\hline & & Phlomis species & Ref \\
\hline & \multicolumn{3}{|l|}{ Flavone glycosides } \\
\hline \multirow[t]{3}{*}{77} & \multirow[t]{3}{*}{ Luteolin 7-O- $\beta$-D-glucopyranoside, $\mathrm{R}=\mathrm{H}$} & Ph. brunneogaleata & [43] \\
\hline & & Ph. lunariifolia & [42] \\
\hline & & Ph. syriaca & [50] \\
\hline 78 & Luteolin 7-O- $\beta$-D-glucuronopyranoside, $\mathrm{R}=\mathrm{H}$ & Ph. floccosa & [55] \\
\hline 79 & Luteolin 7-O-(6"-O- $\alpha$-L-rhamnopyranosyl)- $\beta$-D- glucopyranoside, $\mathrm{R}=\mathrm{H}$ & Ph. capitata & [41] \\
\hline 80 & Luteolin 7-O-(6"-O- $\beta$-D-apiofuranosyl)- $\beta$-D-glucopyranoside, $\mathrm{R}=\mathrm{H}$ & Ph. capitata & [41] \\
\hline 81 & $\begin{array}{l}\text { Luteolin 7-O-[4'"'-O-acetyl- } \alpha \text {-L-rhamnopyranosyl-(1 } \rightarrow 2)]-\beta \text {-D-glucuronopyranoside }{ }^{* *} \text {, } \\
\mathrm{R}=\mathrm{H}\end{array}$ & Ph. lunariifolia & [42] \\
\hline \multirow[t]{7}{*}{82} & \multirow[t]{7}{*}{ Chrysoeriol 7-O- $\beta$-D-glucopyranoside, $\mathrm{R}=\mathrm{CH}_{3}$} & Ph. brunneogaleata & [43] \\
\hline & & Ph. integrifolia & [39] \\
\hline & & Ph. oppositiflora & [47] \\
\hline & & Ph. capitata & [41] \\
\hline & & Ph. Iunariifolia & [42] \\
\hline & & Ph. syriaca & [50] \\
\hline & & Ph. integrifolia & [38] \\
\hline 83 & Chrysoeriol 7-O-(3"'-O-p-coumaroyl)- $\beta$-D-glucopyranoside, $\mathrm{R}=\mathrm{CH}_{3}$ & Ph. integrifolia & [38] \\
\hline 84 & Chrysoeriol 7-O- $\beta$-D-allopyranosyl-( $1 \rightarrow 2)$ - $\beta$-D-glucopyranoside, $\mathrm{R}=\mathrm{CH}_{3}$ & Ph. sintenisii & [34] \\
\hline 85 & $\begin{array}{l}\text { Chrysoeriol 7-O-[6"''-O-acetyl- } \beta \text {-D-allopyranosyl-( } 1 \rightarrow 2)]-\beta \text {-D-glucopyranoside } \\
\text { (= stachyspinoside), } \mathrm{R}=\mathrm{CH}_{3} \\
\text { Flavonol glycosides }\end{array}$ & Ph. sintenisii & [34] \\
\hline 86 & Kaempferol 7-O- $\beta$-D-glucopyranoside, $\mathrm{R}=\mathrm{H}$ & Ph. oppositiflora & [47] \\
\hline \multirow[t]{2}{*}{87} & Quercetin 3-O- $\beta$-D-glucopyranoside, $\mathrm{R}=\mathrm{OH}$ & Ph. oppositiflora & [47] \\
\hline & \multicolumn{3}{|l|}{ Methoxyflavones } \\
\hline 88 & 3-O-methyl-kaempferol, $\mathrm{R}=\mathrm{H}$ & Ph. viscosa & [45] \\
\hline \multirow[t]{2}{*}{89} & 3,3'-di-O-Methyl-quercetin, $\mathrm{R}=\mathrm{OCH}_{3}$ & Ph. viscosa & [45] \\
\hline & \multicolumn{3}{|l|}{ Flavanone } \\
\hline \multirow[t]{2}{*}{90} & \multirow[t]{2}{*}{ Naringenin } & Ph. syriaca & [50] \\
\hline & & Ph. angustissima & [48] \\
\hline
\end{tabular}

Ph. monocephala [58], Ph. sieheana [58]); antimicrobial (Ph. sieheana [74]); antioxidant (Ph. armeniaca [59], Ph. bourgaei [64], Ph. leucophracta [75], Ph. nissolii [75], Ph. pungens [60]); and enzyme-inhibitory (Ph. armeniaca [60], Ph. nissolii [75], Ph. pungens [60]).

\section{Concluding Remarks}

Our studies on Phlomis species resulted in the isolation of many iridoids (1-21) and PhEts (22-56) as glycosidic compounds. Iridoids are highly oxygenated ( $\vee$ Fig. 2 ). They are biogenetically derived from either 8 -epi-loganin without 8 -O-substitution or mussaenoside with 8 -O-substitution involving further hydroxylation at positions 5, 6, and 7 and esterification or formation of iridoids with a 7,8-epoxy group as reported by Alipieva et al. [96]. Chlorotuberoside (18) and phloyosides II (114) are 2 chloro-substituted iridoids isolated from P. tuberosa [49] and E. laciniata [81]. Iridoids isolated from Eremostachys species were closely related to those iridoids isolated from Phlomis species, indicating a close relationship within the same tribe of Phlomideae.

PhEts from Phlomis and Eremostachys species include di-, tri-, and tetraglycosides (22-56) ( (22) or verbascoside (23), which have 3-O-( $\alpha$-L-rhamnopyranosyl)- $\beta$-D-glucopyranoside as oligosaccharide moiety, build the core structure for all tri- and tetraglycosidic compounds. The third and fourth sugars are apiose, arabinose, xylose, lyxose, rhamnose, or glucose whereas apiose is the most abundant. 
<smiles>[R20]OC(C)/C(C)=C/CC[C@]([R20])(C)C=C</smiles>

$91 R_{1}=\beta-G l c, R_{2}=H$

$92 R_{1}=H, R_{2}=\beta-G l c$<smiles>C=C[C@]1(C)C=C2CC[C@H]3C(C)CCCC3(C)[C@H]2[C@H](O)C1</smiles>

93

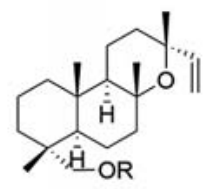

$94 \mathrm{R}=\mathrm{H}$

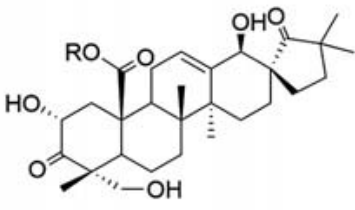

$96 \mathrm{R}=$

$\beta$-Glc

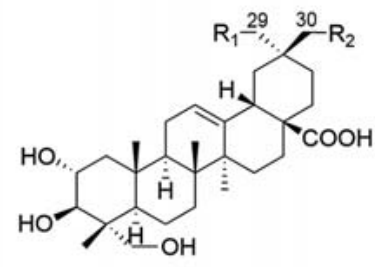

$97 R_{1}=\beta-G l c, R_{2}=H$ $98 R_{1}=H, R_{2}=\beta-G l c$

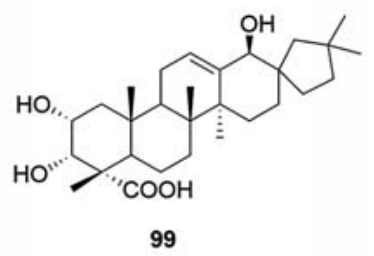

- Fig. 11 Mono-, di-, and triterpenoids from Phlomis species.

- Table 11 Mono-, di-, and triterpenoids from Phlomis species (91-100) (see $>$ Fig. 11).

\begin{tabular}{|c|c|c|c|}
\hline & & Phlomis species & Refs \\
\hline & Monoterpenes & & \\
\hline \multirow[t]{4}{*}{91} & \multirow[t]{4}{*}{ Betulalbuside A } & Ph. armeniaca & [19] \\
\hline & & Ph. sieheana & [30] \\
\hline & & Ph. carica & [37] \\
\hline & & Ph. capitata & [41] \\
\hline \multirow[t]{2}{*}{92} & 1-Hydroxylinaloyl 6-O- $\beta$-D-glucopyranoside & Ph. carica & [37] \\
\hline & \multicolumn{3}{|l|}{ Diterpenes } \\
\hline 93 & Amanicadol & Ph. amanica & [51] \\
\hline 94 & Jhanol & Ph. bourgei & [15] \\
\hline \multirow[t]{2}{*}{95} & Jhanol acetate & Ph. borgei & [15] \\
\hline & \multicolumn{3}{|l|}{ Triterpenes and Nortriterpenes } \\
\hline 96 & $\begin{array}{l}\text { Norviscoside: (17S)-2 } \alpha, 18 \beta, 23 \text {-trihydroxy-3,19-dioxo-19(18 } \rightarrow 17) \text {-abeo-28- } \\
\text { norolean-12-en-25-oic acid 25-O-glucopyranosyl ester }\end{array}$ & Ph. viscosa & [40] \\
\hline 97 & Viscoside A & Ph. viscosa & [40] \\
\hline 98 & Viscoside B & Ph. viscosa & [40] \\
\hline 99 & $2 \alpha, 3 \alpha, 18 \beta$-Trihydroxy-19(18 $\rightarrow 17)$-abeo-28-norolean-12-en-23-oic acid & Ph. integrifolia & [27] \\
\hline 100 & $2 \alpha, 3 \alpha, 18 \beta, 23$-Tetrahydroxy-19(18 $\rightarrow 17)$-abeo-28-norolean-12-en & Ph. integrifolia & [27] \\
\hline
\end{tabular}

During our studies on Phlomis species, priority has been given to iridoids and phenylethanoids. Therefore, it would not be correct to generalize with the structures and numbers of compounds other than iridoids and phenylethanoids. Other compounds have been presented here to show the structural diversity of the chemical constituents of Phlomis species.
Neo-, oxy-, and lignan glycosides are the third major group of metabolites isolated. Neolignans are mostly diconiferyl alcohol derivatives (57-65). Lignans are furofuran-type (66-67) or tetrahydrofuran-type lignans (68). Flavonoids are mostly flavone glycosides of luteolin and chrysoeriol (77-85). Few flavonols are 


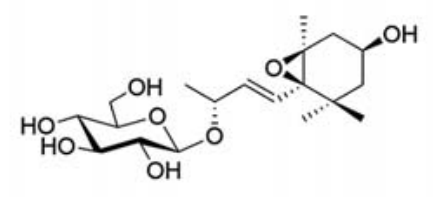

101<smiles></smiles>

102<smiles>O=c1ccn2c(c1)[C@H](O)[C@H](O)[C@H](O)[C@H]2O</smiles>

103

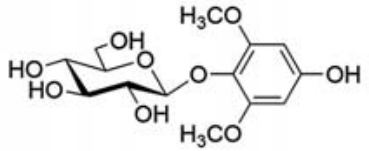

104

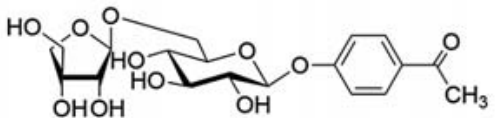

105

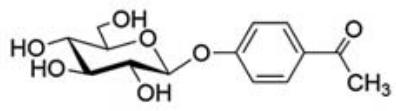

106

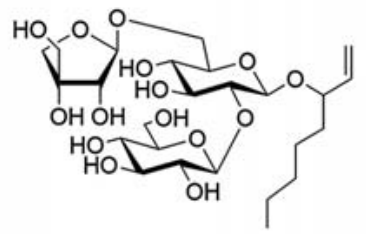

107

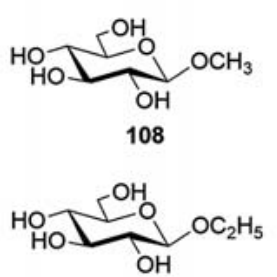

109

- Fig. 12 Miscellaneous metabolites from Phlomis species.

- Table 12 Miscellaneous metabolites from Phlomis species (101-109) (see $>$ Fig. 12).

\begin{tabular}{|c|c|c|c|}
\hline & Compounds & Phlomis species & Refs \\
\hline \multirow[t]{3}{*}{101} & \multirow[t]{3}{*}{ Phlomuroside } & Ph. samia & [37] \\
\hline & & Ph. viscosa & [45] \\
\hline & & Ph. carica & [37] \\
\hline 102 & $(2 R, 4 S)$-2-Carboxy-4-(E)-p-coumaroyloxy-1,1-dimethylpyrolidinium inner salt & Ph. brunneagaleata & [43] \\
\hline 103 & Uridine & Ph. samia & [37] \\
\hline \multirow[t]{2}{*}{104} & \multirow[t]{2}{*}{ 2,6-Dimetoxy-4-hydroxyphenyl-1-O- $\beta$-D-glucopyranoside } & Ph. samia & [37] \\
\hline & & Ph. carica & [37] \\
\hline \multirow[t]{2}{*}{105} & \multirow[t]{2}{*}{ 4-Hydroxyacetophenon 4-O-(6'-O- $\beta$-D-apiofuranosyl)- $\beta$-D-glucopyranoside } & Ph. brunneogaleata & [43] \\
\hline & & Ph. kotschyana & [44] \\
\hline 106 & Picein & Ph. carica & [37] \\
\hline 107 & $\begin{array}{l}\text { Lunaroside }[1 \text {-octen-3yl } O \text { - } \beta \text {-apiofuranosyl- }(1 \rightarrow 6) \text {-O-[ } \beta \text {-glucopyranosyl- }(1 \rightarrow 2)]- \\
\beta \text {-glucopyranoside }]\end{array}$ & Ph. Iunarifolia & [42] \\
\hline \multirow[t]{2}{*}{108} & \multirow[t]{2}{*}{ 1-O-Methyl- $\beta$-D-glucopyranoside } & Ph. bourgaei & \\
\hline & & Ph. tuberosa & [49] \\
\hline 109 & 1-O-Ethyl- $\beta$-D-glucopyranoside & Ph. oppositiflora & [47] \\
\hline
\end{tabular}

kaempferol and quercetin derivatives (86-89). A flavanone, naringenin (90), was only isolated from 2 Phlomis species.

Terpenoids are another metabolite group, represented by 10 compounds (91-100), which are mono-, di-, and triterpenoids. Particularly interesting are the 28-noroleanane-derived spirocyclic triterpenoids (96, and 99-100). Similar triterpenoids that display this rare type of spirocyclic skeleton have also been isolated from the rhizomes of the Chinese medicinal plant $P$. umbrosa, which is used to treat colds, reduce swelling, and staunch bleeding [9799]. Metabolites belonging to further chemical classes include a megastigmane glycoside (101), 2 acetophenone glycosides (105-106), and an octenol triglycoside (107).

Almost all Phlomis species of Turkey and 2 species from Northern Cyprus have been analyzed for essential oils. Phlomis essential oils are characterized by low yields and by the occurrence of sesquiterpenes as main constituents. Germacrene D and $\beta$-caryo- 
- Table 13 Constituents of Phlomis spp. essential oils.

\begin{tabular}{|c|c|c|}
\hline Species & Main Compounds (\%) & References \\
\hline Ph. amanica* & $\begin{array}{l}\text { 8(14),15-Isopimaradien-11 } \alpha \text {-ol ( } 23 \%), \text { germacrene-D (15\%), bicyclo-germacrene (11\%), } \\
\text { (Z)- } \beta \text {-farnesene ( } 8 \%)\end{array}$ & {$[57-58]$} \\
\hline Ph. angustissima* & Hexadecanoic acid (19\%) & {$[58]$} \\
\hline \multirow[t]{4}{*}{ Ph. armeniaca* } & Germacrene D (23\%), (Z)- $\beta$-farnesene (6\%), hexadecanoic acid (5\%) & {$[57-58]$} \\
\hline & Germacrene D (27-23\%), (E)-2-hexenal 10-12, $\beta$-caryophyllene (12-17\%) & [59] \\
\hline & Germacrene D (24\%), hexadecanoic acid (22\%), hexahydrofarnesyl acetone (14\%) & {$[60]$} \\
\hline & $\begin{array}{l}\text { Germacrene D (36\%), } \beta \text {-caryophyllene (18\%), caryophyllene oxide (13\%), (E)- } \beta \text {-farnesene } \\
(7 \%) \text {, hexahydrofarnesyl acetone (7\%) }\end{array}$ & {$[61]$} \\
\hline Ph. x bornmuelleri* & $\beta$-Caryophyllene (17\%), germacrene D (17\%) & {$[58]$} \\
\hline \multirow[t]{4}{*}{ Ph. bourgaei* } & $\beta$-Caryophyllene (15-22\%), $\alpha$-cubebene (14-16\%), germacrene-D (11-15\%) & [59] \\
\hline & Germacrene D (11\%), $\beta$-caryophyllene (11\%), manoyl oxide (4\%) & {$[62]$} \\
\hline & $\alpha$-Cubebene (13-17\%), $\beta$-caryophyllene (11-12\%), germacrene D (11-13\%) & {$[63]$} \\
\hline & $\beta$-Caryophyllene (37\%), (Z)- $\beta$-farnesene (16\%), germacrene D (11\%) & [64] \\
\hline Ph. brevibracteata** & $\begin{array}{l}\text { leaf: Caryophyllene oxide ( } 24 \%), \beta \text {-caryophyllene }(22 \%) \\
\text { flower: } \beta \text {-Caryophyllene (265), caryophyllene oxide (7\%) }\end{array}$ & {$[65]$} \\
\hline Ph. bruguieri & Germacrene $\mathrm{D}(31 \%)$, hexadecanoic acid (22\%), (Z)- $\beta$-farnesene (12\%) & {$[58]$} \\
\hline Ph. brunneogaleata* & $\beta$-Caryophyllene (25\%), hexadecanoic acid (17\%), germacrene D (16\%) & {$[58]$} \\
\hline Ph. capitata* & $\beta$-Caryophyllene (22\%), germacrene D (12\%) & {$[58]$} \\
\hline \multirow[t]{2}{*}{ Ph. chimerae* } & $\beta$-Caryophyllene (32\%), $\alpha$-pinene (11\%), limonene (6\%) & {$[66]$} \\
\hline & $\beta$-Caryophyllene (35\%), germacrene D (16\%), caryophyllene oxide (6\%) & {$[61]$} \\
\hline Ph. cypria** & $\begin{array}{l}\text { leaf: } \beta \text {-Caryophyllene ( } 37 \%) \text {, germacrene D ( } 21 \%) \\
\text { flower: } \beta \text {-Caryophyllene ( } 48 \%) \text {, germacrene D }(17 \%)\end{array}$ & [65] \\
\hline \multirow[t]{4}{*}{ Ph. grandiflora var. grandiflora* } & $\beta$-Eudesmol (61-62\%), $\beta$-curcumene (3-6\%), ar-curcumene ( $2 \%$ ) & {$[67]$} \\
\hline & $\beta$-Eudesmol (42\%), $\alpha$-eudesmol (16\%), ar-curcumene (3\%) & {$[68]$} \\
\hline & $\alpha$-Pinene (19-26\%), $\alpha$-cedrene (19-28\%), $\alpha$-curcumene (12-14\%) & [59] \\
\hline & $\alpha$-Cedrene (26-31\%), $\alpha$-pinene (23-24\%), $\alpha$-curcumene (8-14\%) & {$[63]$} \\
\hline Ph. integrifolia* & Germacrene D (20\%), (Z)- $\beta$-Farnesene (13\%) & {$[58]$} \\
\hline Ph. kotschyana & Hexadecanoic acid (17\%), germacrene D (14\%), $\beta$-caryophyllene (4\%) & {$[58]$} \\
\hline Ph. kurdica & $\beta$-Caryophyllene (31\%), (Z)- $\beta$-farnesene (14\%), germacrene D (2\%) & {$[58]$} \\
\hline \multirow[t]{5}{*}{ Ph. leucophracta* } & $\beta$-Caryophyllene (20-22\%), limonene (11-15\%), (E)-2-hexenal (8-9\%) & [59] \\
\hline & $\beta$-Caryophyllene (23\%), limonene (15\%), (E)-2-hexenal (9-11\%) & {$[63]$} \\
\hline & $\beta$-Caryophyllene (20\%), $\alpha$-pinene (20\%), limonene (11\%) & {$[66]$} \\
\hline & $\beta$-Caryophyllene (23\%), germacrene D (10\%) & {$[58]$} \\
\hline & Linalool (36\%), $\beta$-caryophyllene (8\%), caryophyllene oxide ( $8 \%$ ), spathulenol (8\%) & [75] \\
\hline \multirow[t]{2}{*}{ Ph. linearis } & $\begin{array}{l}\text { Germacrene D (17\%), chrysanthenyl acetate (6\%), trans-chrysanthenol (6\%), } \\
\text { 2-pentadecanone (5\%) }\end{array}$ & [69] \\
\hline & $\beta$-Caryophyllene (24\%), germacrene D (22\%) & {$[70]$} \\
\hline Ph. longifolia var. bailanica & $\beta$-Caryophyllene (19\%), germacrene D (18\%) & {$[58]$} \\
\hline Ph. Iunariifolia & $\begin{array}{l}\text { Hexadecanoic acid (10\%), } \beta \text {-caryophyllene (9\%), germacrene-D ( } 8 \%) \text {, } \\
8(14), 15 \text {-isopimaradien- } 11 \alpha \text {-ol (6\%) }\end{array}$ & ${ }^{[57]}$ con \\
\hline
\end{tabular}


- Table 13 Continued

\begin{tabular}{|c|c|c|}
\hline Species & Main Compounds (\%) & References \\
\hline \multirow[t]{3}{*}{ Ph. lycia* } & Germacrene-D (16\%), $\beta$-caryophyllene (18\%), limonene (14\%) & [59] \\
\hline & Germacrene D (25-27\%), $\beta$-caryophyllene (23-26\%), limonene (6-11\%) & [63] \\
\hline & $\beta$-Caryophyllene (21\%), germacrene D (11\%) & [58] \\
\hline Ph. $\mathrm{x}$ melitenense & Germacrene D (27\%), $\beta$-caryophyllene (2\%) & {$[58]$} \\
\hline \multirow[t]{2}{*}{ Ph. monocephala* } & 8(14),15-Isopimaradien-11 $\alpha$-ol (13\%), cermacrene D (6\%), manoyl oxide (6\%) & [57] \\
\hline & Germacrene D 19, (E)- $\beta$-farnesene (18\%), $\alpha$-pinene (16\%) & [71] \\
\hline \multirow[t]{5}{*}{ Ph. nissolii* } & Limonene (16-24\%). $\beta$-caryophyllene (10-13\%), germacrene-D (12-21\%) & [59] \\
\hline & $\begin{array}{l}\text { Germacrene D (34\%), bicyclogermacrene (15\%), (Z)- } \beta \text {-farnesene (11\%), } \beta \text {-caryophyllene } \\
(9 \%)\end{array}$ & [72] \\
\hline & Limonene (15-21\%), $\beta$-caryophyllene (14\%), germacrene $\mathrm{D}(8 \%)$ & [63] \\
\hline & $\begin{array}{l}\text { Germacrene D (15\%), } \beta \text {-caryophyllene (13\%), hexahydrofarnesyl acetone (12\%), } \\
\text { linalool (11\%) }\end{array}$ & [75] \\
\hline & Germacrene D (25\%), $\beta$-caryophyllene (8\%) & [58] \\
\hline \multirow[t]{2}{*}{ Ph. oppositiflora* } & $\begin{array}{l}\text { Germacrene D ( } 23 \%) \text {, germacrene B ( } 15 \%) \text {, bicyclogermacrene }(9 \%) \text {, camphor }(6 \%) \text {, } \\
\text { caryophyllene oxide }(5 \%)\end{array}$ & [69] \\
\hline & $\begin{array}{l}\beta \text {-Caryophyllene (8\%), germacrene D (6\%), spathulenol (6\%), } \gamma \text {-elemene (6\%), } \\
\text { bicyclogermacrene (5\%), caryophyllene oxide (5\%) }\end{array}$ & [58] \\
\hline Ph. physocalyx* & (Z)- $\beta$-Farnesene (6\%), germacrene D (5\%), $\beta$-caryophyllene (4\%) & [58] \\
\hline Ph. pungens var. hirta & Germacrene D (15\%) & [58] \\
\hline Ph. pungens var. hispida & $\beta$-Caryophyllene (24\%), cermacrene D (23\%) & [58] \\
\hline \multirow[t]{3}{*}{ Ph. pungens var. pungens } & (E)-2-Hexenal (13-18\%), vinyl amyl carbinol (13-19\%), germacrene-D (8-10\%) & [59] \\
\hline & Vinyl amyl carbinol (13-19\%), (E)-2-hexenal (17-18\%), germacrene D (8\%) & [59] \\
\hline & Hexadecanoic acid (68\%), germacrene D (7\%) & {$[60]$} \\
\hline \multirow[t]{3}{*}{ Ph. rigida* } & $\beta$-Caryophyllene (31-39\%), $\beta$-selinene (13-15\%), caryophyllene oxide (4-5\%) & [73] \\
\hline & B-Caryophyllene (60\%), germacrene D (10\%), (E)-2-hexenal (9\%) & [71] \\
\hline & epi-Zonarene (14\%), d-cadinene (11\%), spathulenol (11\%), $\alpha$-copaene (8\%) & [69] \\
\hline Ph. russeliana* & $\beta$-Caryophyllene (22\%), germacrene-D (15\%), caryophyllene oxide (8\%) & [68] \\
\hline \multirow[t]{3}{*}{ Ph. samia } & Germacrene D (34\%), $\beta$-caryophyllene (6\%) & [73] \\
\hline & Germacrene-D (19-23\%), $\beta$-caryophyllene (14-15\%), $\alpha$-copaene (10-11\%) & [59] \\
\hline & Germacrene D (17\%), $\alpha$-copaene (8-15\%), $\beta$-caryophyllene (9-14\%) & [63] \\
\hline \multirow[t]{2}{*}{ Ph. sieheana* } & Germacrene D (16\%), $\beta$-caryophyllene (11\%), $\alpha$-pinene ( $8 \%)$ & [74] \\
\hline & $\begin{array}{l}\text { Germacrene } D(17 \%),(Z)-\beta \text {-farnesene (12\%), spathulenol (3\%), hexahydrofarnesyl acetone } \\
(2 \%) \text {, hexadecanoic acid ( } 2 \%)\end{array}$ & [57-58] \\
\hline Ph. sintenisii* & spathulenol (7\%) & {$[58]$} \\
\hline Ph. syriaca & $\beta$-Bisabolol (42\%), germacrene D (16\%), $\beta$-caryophyllene (4\%) & [58] \\
\hline Ph. viscosa & $\begin{array}{l}\text { 8,13-Epoxy-15,16-dinorlabd-12-ene (22\%), germacrene D ( } 9 \%), \beta \text {-caryophyllene ( } 8 \%) \text {, } \\
\text { germacrene B (6\%), } 8,13 \text {-epoxy-14-labdene (manoyl oxide) }(1 \%), 8,13 \text {-epoxy-14-epi- } \\
\text { labdene (epi-manoyl oxide) (1\%), sclareolide ( } 3 \%) \text {, ambrox }(1 \%) \text {, phytol }(1 \%)\end{array}$ & [58] \\
\hline Ph. $\mathrm{x}$ vuralii & Caryophyllene oxide (17\%), 8,12-epoxy-labd-14-en-13-ol (6\%) & {$[61]$} \\
\hline
\end{tabular}




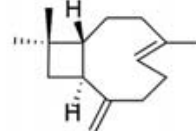

$\beta$-Caryophyllene

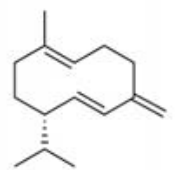

Germacrene D

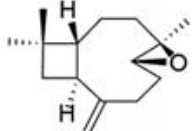

$\beta$-Caryophyllene oxide

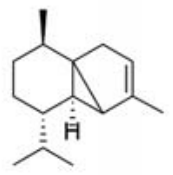

$\alpha$-Cubebene

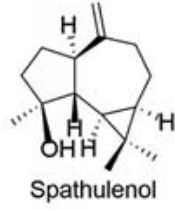<smiles>C=C1CCC[C@]2(C)CC[C@@H](C(C)(C)O)C[C@H]12</smiles>

$\beta$-Eudesmol

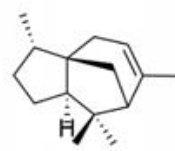

$\alpha$-Cedrene<smiles>C=CC(=C)CCC=C(C)CCC=C(C)C</smiles>

$\beta$-Farnesene

- Fig.13 Major sesquiterpenes found in Phlomis essential oils.

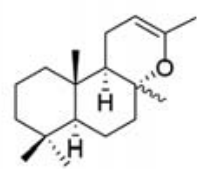

8,13-Epoxy-15,16dinorlabd-12-ene

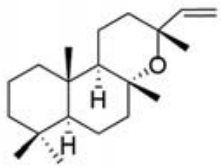

Manoyl oxide

8,13-epoxy-

14-Labdene

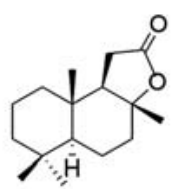

Sclareolide

$13,14,15,16$-Tetranor-

12,8-labdanolide

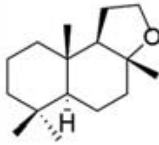

Ambrox

8,12-epoxy-

$13,14,15,16-$ Tetranorlabdane

- Fig. 14 Diterpenes found in Phlomis essential oils.

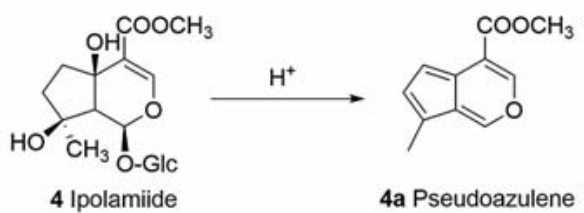

- Fig. 15 Acid-catalyzed degradation of ipolamiide (4) to a fulvoiridoid (= pseudoazulene) (4a).

phyllene are the typical sesquiterpenes found in $75 \%$ of the oils. Some Phlomis oils like the oil from $P$. viscosa are rich in diterpenes. 8(14),15-Isopimaradien-11 $\alpha$-ol, a recently described diterpene, was found in 3 Phlomis species. Some Phlomis oils have been tested for antimicrobial, antioxidant, and enzyme-inhibitory activities.

Our studies focused on the iridoids and PhEts and were performed on Phlomis and Eremostachys species. They have resulted in the isolation of more than 100 metabolites including a wide range of chemical classes as summarized above. These results indicate not only the chemical diversity of the metabolites isolated but also the potential biological and pharmacological activities of plants of the family Lamiaceae for drug discovery studies. In this context, a recent review article on the antimalarial active compounds from the plants of Lamiaceae underlines their potential in the search for lead compounds [100]. The potential of Lamiaceae is also emphasized by a recent review focusing on flavonoids, fatty acid derivatives, and sterols and their wide range of biological activities [101].

Taken together, these observations show that the members of this family are still a highly interesting group of plants for further taxonomic, phytochemical, biological, and pharmacological studies.

\section{Funding}

The studies performed on the Phlomis L. species were supported by The Scientific and Technological Research Council of Turkey (TUBITAK-SBAG-2304).

\section{Contributors' Statement}

Conception and design of the work: i. Çalış; data collection: i. Çalış, K. H. C. Başer; drafting the manuscript: i. Çalış; critical revision of the manuscript: İ. Çalış, K. H.C. Başer. 
<smiles>COC(=O)C1=COC(OCl)C2C1[C@@H](C)[C@@H](O)C2O</smiles>

$1106 \beta$-Hydroxy-7-epi-loganin<smiles>COC(=O)C1=COC(O[Cl+3])C2[C@](C)(O)[C@H](O)[C@@H](O)[C@@]12O</smiles>

113 Phloyoside I<smiles>C[N+](C)(C)CCO</smiles>

111 Lamalbidic acid choline salt

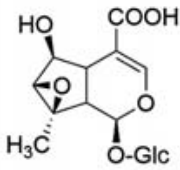

112 5-Deoxy-sesamosidic acid

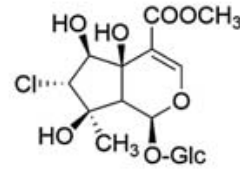

114 Phloyoside II

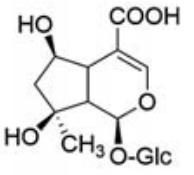

115 Shanzhizide

- Fig. 16 Iridoids from Eremostachys species (110-115).

\section{Acknowledgements}

The authors kindly thank Ali A Dönmez (Hacettepe University, Department of Biology, Ankara, Turkey), MY Dadandı (Erciyes University, Faculty of Science and Letters, Department of Biology, Erciyes, Turkey), i Saracoğlu, T Ersöz, H Kırmızbekmez, FN Yalçın, US Harput (Hacettepe University, Faculty of Pharmacy Department of Pharmacognosy, Ankara, Turkey), Randa Aldaba and Azmi Hanoğlu (Near East University, Faculty of Pharmacy Department of Pharmacognosy, Lefkoşa, TRNC), Mehmet Koyuncu and Ayşegül Köroğlu (Ankara University, Faculty of Pharmacy, Ankara, Turkey), Betül Demirci and Fatih Demirci (Anadolu University Faculty of Pharmacy, Department of Pharmacognosy, Eskişehir, Turkey) and other co-authors for their participation in the studies performed on the Phlomis and Eremostachys species. Our thanks also go to F Celep (Department of Biology, Faculty of Arts and Sciences, Kırıkkale University, Kırıkkale, Turkey) for his kind help in the taxonomy of Lamiaceae and its subfamilies and tribes based on his recent phylogenomic studies.

\section{Conflict of Interest}

The authors declare that they have no conflict of interest.

\section{References}

[1] Celep F, Dirmenci T. Systematic and biogeographic overview of Lamiaceae in Turkey. Nat Volatiles \& Essent Oils 2017; 4: 14-27

[2] Harley RM, Reynolds T. Advances in Labiatae Science. Royal Botanic Gardens, Kew, Whitstable, Kent, Great Britain. Kew: Royal Botanic Gardens; 1992

[3] Rogenmoser E. Isolierung, Charakterisierung und Strukturaufklärung der Iridoidglucoside von Galeopsis pubescens Besser. [Dissertation] Zürich: ETH No 5574 Juris Druck + Verlag Zürich; 1975

[4] Çalış I, Lahloub MF, Rogenmoser E, Sticher O. Isomartynoside, a phenylpropanoid glycoside from Galeopsis pubescens. Phytochemistry 1984: 23, 2313-2315

[5] Harborne JB. Caffeic acid distribution in higher plants. Z Naturforsch Teil B 1966; 21: 604-605

[6] Jimenez C, Riguera R. Phenylethanoid glycosides in plants: structure and biological activity. Nat Prod Rep 1994; 11: 591-606

[7] Çalış I, Gross GA, Sticher O. Phenylpropanoid glycosides isolated from Scrophularia scopolii. Phytochemistry 1987; 26: 2057-2061
[8] Çalış İ, Gross GA, Sticher O. Two Phenylpropanoid glycosides from Scrophularia scopolii. Phytochemistry 1988; 27: 1465-1468

[9] Çalış I, Gross GA, Winkler T, Sticher O. Isolation and structure elucidation of two highly acylated iridoid diglycosides from Scrophularia scopolii. Planta Med 1988; 54: 168-170

[10] Jeker M, Sticher O, Çalış I, Rüedi P. Allobetonicoside and 6-O-acetylmioporoside from Betonica officinalis L Helv Chim Acta 1989; 72: 1787-1791

[11] Basaran AA, Çalış I, Anklin C, Nishibe S, Sticher O. Lavandulifoliosidea new phenylpropanoid glycoside from Stachys lavandulifolia. Helv Chim Acta 1988; 71: 1483-1490

[12] Çalış İ, Basaran AA, Saracoğlu I, Sticher O, Rüedi P. Phlinosides A, B and C, three phenylpropanoid glycosides from Phlomis linearis. Phytochemistry 1990; 29: 1253-1257

[13] Çalış I, Basaran AA, Saracoğlu I, Sticher O, Rüedi P. Phlinosides D and E, phenylpropanoid glycosides, and iridoids from Phlomis linearis. Phytochemistry 1991; 30: 3073-3075

[14] Basaran AA, Saracoğlu I, Çalıs İ. Iridoid glucosides isolated from Phlomis linearis. Hacettepe Univ J Faculty Pharmacy 1991; 11: 81-88

[15] Harput US, Saracoğlu I, Çalış I, Kojima K, Ogihara Y. Diterpenoids from Phlomis bourgaei Boiss. In: Çalış I, Ersöz T, Başaran AA, eds. Proceedings of XIIth Int. Symposium on Plant Originated Crude Drugs. Ankara, Turkey 1998: 127-131

[16] Harput US, Saracaoglu I, Çalış I. Iridoid and phenylethanoid glycosides from Phlomis bourgaei. Hacettepe Univ J Faculty Pharmacy 1999; 19: 1-9

[17] Akdemir Z, Çalış I, Junior P. Iridoids and phenylpropanoid glycosides from Pedicularis nordmanniana. Planta Med 1991; 57: 584-585

[18] Çalış İ, Tasdemir D, Wright AD, Sticher O. Lagotoside: a new phenylpropanoid glycoside from Lagotis stolonifera. Helv Chim Acta 1991; 74: 1273-1277

[19] Saracoğlu I, Inoue M, Çalış I, Ogihara Y. Studies on constituents and cytostatic activity of two Turkish medicinal plants Phlomis armeniaca and Scutellaria salviifolia. Biol Pharm Bull 1995; 18: 1396-1400

[20] Cantino PD, Harley RM, Wagstaff SJ. Genera of Labiatae: Status and Classification. In: Harley RM, Reynolds T, eds. Advances in Labiatae Science. Royal Botanic Gardens, Kew, Whitstable, Kent, Great Britain. Kew: Royal Botanic Gardens; 1992: 511-522

[21] Janicsák G, Máthé I, Miklóssy-Vari V, Blunden G. Comparative studies of the rosmarinic and caffeic acid contents of Lamiaceae species. Biochem Syst Ecol 1999; 27: 733-738 
[22] Pedersen JA. Distribution and taxonomic implications of some phenolics in the family Lamiaceae determined by ESR spectroscopy. Biochem Syst Ecol 2000; 28: 229-253

[23] Li B, Cantino PD, Olmstead RG, Bramley GLC, Xiang CL, Ma ZH, Tan YH, Zhang DX. A large-scale chloroplast phylogeny of the Lamiaceae sheds new light on its subfamilial classification. Sci Rep 2016; 6: 34343

[24] Li B, Olmstead RG. Two new subfamilies in Lamiaceae. Phytotaxa 2017; 313: $222-226$

[25] Zhao F, Chen YP, Salmaki Y, Drew BT, Wilson TC, Scheen AC, Celep F, Bräucler C, Bendiksby M, Wang Q, Min DZ, Peng H, Olmstead RG, Li B, Xiang CL. An updated tribal classification of Lamiaceae based on plastome phylogenomics. BMC Biol 2021; 19: 2. doi:10.1186/s12915-02000931-z

[26] Davis PH. Flora of Turkey and the East Aegean Island. Vol. VII. Edinburgh: University Press; 1982: 36-463

[27] Çalış i, Saracoğlu i, Ersöz T, Dönmez AA, Kırmızıbekmez H, Yalçın FN, Harput Ş. Chemotaxonomy of the Genus Phlomis L. (Lamiaceae) in Turkey. TÜBiTAK Project, Project Number SBAG-2304. Ankara: Tubitak; 2004

[28] Ersöz T, Schühly W, Popov S, Handjieva N, Sticher O, Çalış I. Iridoid and phenylethanoid glycosides from Phlomis longifolia var. longifolia. Nat Prod Lett 2001; 15: 345-351

[29] Ersöz T, Ivancheva S, Akbay P, Sticher O, Çalış İ. Iridoid and Phenylethanoid glycosides from Phlomis tuberosa L. Z Naturforsch 2001; 56c: 695698

[30] Ersöz T, Harput US, Çalış I, Dönmez AA. Iridoid, phenylethanoid and monoterpene glycosides from Phlomis siehana. Turk J Chem 2002; 26: 1-8

[31] Ersöz T, Saracoğlu I, Harput US, Çalış I, Dönmez AA. Iridoid and phenylpropanoid glycosides from Phlomis grandiflora var. fimbrilligera and Phlomis fruticosa. Turk J Chem 2002; 26: 171-178

[32] Ersöz T, Saracoğlu I, Taşdemir D, Kırmızıbekmez H, Dönmez AA, Ireland CM, Çalış I. Neolignan glucosides from Phlomis chimerae Boiss. Z Naturforsch 2002; 57c: 221-225

[33] Saracoğlu i, Harput US, Çalış I, Ogihara Y. Phenolic constituents from Phlomis lycia. Turk J Chem 2002; 26: 133-142

[34] Çalıs i, Kırmızıbekmez H, Ersöz T, Saracoğlu i, Dönmez AA, Mitova M, Handjieva N, Popov S. Iridoid, phenylethanoid and flavonoid glycosides from Phlomis sintenisii. Acta Pharmaceutica Turcica 2002: 44; 195-203

[35] Yalçın FN, Ersöz T, Akbay P, Çalıs İ, Dönmez AA, Sticher O. Iridoid and phenylpropanoid glycosides from Phlomis samia, P. monocephala and P. carica. Turk J Chem 2003; 27: 295-305

[36] Ersöz T, Alipieva KI, Yalçın FN, Akbay P, Handjieva N, Dönmez AA, Popov $S$, Çalış I. Physocalycoside, a new phenylethanoid glycoside from Phlomis physocalyx Hub. Mor Z Naturforsch 2003; 58c: 471-476

[37] Yalçın FN, Ersöz T, Akbay P, Çalıs İ, Dönmez AA, Sticher O. Phenolic, megastigmane, nucleotide, acetophenone and monoterpene glycosides from Phlomis samia and P. carica. Turk J Chem 2003; 27: 703-711

[38] Saracoğlu i, Varel M, Çalış I, Dönmez AA. Neolignan, Flavonoid, Phenylethanoid and iridoid glycosides from Phlomis integrifolia. Turk J Chem 2003; 27: 739-747

[39] Saracoğlu i, Varel M, Hada J, Hada N, Takeda T, Dönmez AA, Çalıs i. Phenylethanoid glycosides from Phlomis integrifolia Hub. Mor Z Naturforsch 2003; 58c: 820-825

[40] Çalış i, Kırmızıbekmez H, Taşdemir D, Rüedi P. Two new triterpene and a new nortriterpene glycosides from Phlomis viscosa. Helv Chim Acta 2004; 87: 611-619

[41] Kırmızıbekmez H, Piacenta S, Pizza C, Dönmez AA, Çalış İ. Iridoid and phenylethanod glycosides from Phlomis nissolii and P. capitata. Z Naturforsch 2004; 59b: 609-613

[42] Çalış I, Kırmızıbekmez H. Glycosides from Phlomis lunariifolia. Phytochemistry 2004; 65: 2619-2625
[43] Kırmızıbekmez H, Çalış I, Perozzo R, Brun R, Dönmez AA, Linden A, Rüedi $\mathrm{P}$, Taşdemir D. Inhibiting activities of the secondary metabolites of Phlomis brunneogaleata against parasitic protozoa and plazmodial enoyl-ACP reductase, a crucial enzyme in fatty acid biosynthesis. Planta Med 2004; 70: 711-717

[44] Harput US, Saracoğlu I, Çalış I, Dönmez AA, Nagatsu A. Secondary metabolites from Phlomis kotschyana. Turk J Chem 2004; 28: 767-774

[45] Çalış I, Kırmızıbekmez H, Beutler JA, Dönmez AA, Yalçın FN, Kılıç E, Özalp M, Taşdemir D. Secondary metabolites from Phlomis viscosa and their biological activities. Turk J Chem 2005; 29: 71-81

[46] Kırmızıbekmez H, Montoro P, Piacenta S, Pizza C, Dönmez AA, Çalış i. Identification by HPLC-PAD-MS and quantification by HPLC-PAD of phenylethanoid glycosides of five Phlomis species. Phytochem Anal 2005; 16: $1-6$

[47] Çalış I, Bedir E, Kırmızıbekmez H, Ersöz T, Dönmez AA, Khan IA. Secondary metabolites from Phlomis oppositiflora. Nat Prod Res 2005; 19: 493501

[48] Yalçın FN, Ersöz T, Bedir E, Şahpaz S, Bailleul F, Khan IA, Dönmez AA Çalış I. Phlinoside F, a new phenylethanoid glycoside from Phlomis angustissima. Turk J Chem 2005; 29: 417-423

[49] Çalış I, Kırmızıbekmez H, Ersöz T, Dönmez AA, Gotfredsen CH, Jensen SR. Iridoid glucosides from Turkish Phlomis tuberosa. Z Naturforsch 2005; 60b: $1295-1298$

[50] Harput US, Çalış I, Saracoğlu I, Dönmez AA, Nagatsu A. Secondary metabolites from Phlomis syriaca and their antioxidant activities. Turk J Chem 2006; 30: 383-390

[51] Yalçın FN, Ersöz T, Bedir E, Dönmez AA, Stavri MZ, Gibbons S, Çalış i. Amanicadol, a pimarane type diterpene from Phlomis amanica Vierch. Z Naturforsch 2006; 61b: 1433-1436

[52] Saracaoglu I, Kojima K, Harput US, Ogihara Y. A new phenylethanoid glycoside from Phlomis pungens WILLD. var. pungens. Chem Pharm Bull 1998; 46: 726-727

[53] Takeda Y, Kinuguawa M, Masuda T, Honda G, Otsuka H, Sezik E, Yeşilada E. Phlomisethanoside, a phenylethanoid glycoside from Phlomis grandiflora var. grandiflora. Phytochemistry 2000; 51: 321-325

[54] Takeda Y, Matsumara H, Masuda T, Honda G, Otsuka H, Takaishi Y, Sezik E, Yeşilada E. Phlorigidosides A-C, iridoid glucosides from Phlomis rigida. Phytochemistry 2000; 53: 931-935

[55] Hanoğlu A. Phytochemical studies on Phlomis species [Ph.D. Thesis] Nicosia: Near East University. Graduate School of Health Sciences; 2019

[56] Aldaba R. Secondary metabolites from Phlomis floccosa D. DON [MS Thesis]. Nicosia: Near East University. Graduate School of Health Sciences; 2017

[57] Demirci B, Toyota M, Demirci F, Dadandı MY, Başer KHC. Anticandidal pimaradiene diterpene from Phlomis essential oils. Comptes Rendus Chimie 2009; 12: 612-621

[58] Başer KHC, Demirci B, Yüzbașıŏlu E, Dadandı MY. Essential oils of Phlomis species of Turkey. 37th International Symposium on Essential Oils (37th ISEO). September 10-13, 2006; Grasse-Opio, France

[59] Sarıkaya AG, Fakir H. The effect of reaping times on volatile components of natural Phlomis L. (Lamiaceae) taxa in the lakes district of Turkey. Applied Ecol Environ Res 2016; 14: 753-772

[60] Sarıkürkçü C, Uren MC, Koçak MS, Cengiz M, Tepe B. Chemical composition, antioxidant, and enzyme inhibitory activities of the essential oils of three Phlomis species as well as their fatty acid compositions. Food Sci Biotechnol 2016; 25: 687-693

[61] Yaşar S, Fakir H, Erbaş S. Gas chromatographic (GC-GC/MS) analysis of essential oil of Phlomis armeniaca Willd. From Mediterranean region of Turkey. Asian J Chem 2010; 22: 2887-2890

[62] Başer KHC, Demirci B, Dadandı MY. Comparative essential oil composition of the natural hybrid Phlomis x vuralii Dadandi (Lamiaceae) and its parents. J Essent Oil Res 2008; 20: 57-62 
[63] Sarikaya AG, Fakir H. Determination of volatile components of natural Phlomis L. (Lamiaceae) taxa on different elevations of the lakes district in Turkey. J Anim Plant Sci 2018; 28: 552-560

[64] Sarıkürkçü C, Özer MS, Çakır A, Eskici M, Mete E. GC/MS evaluation and in vitro antioxidant activity of essential oil and solvent extracts of an endemic plant used as folk remedy in Turkey: Phlomis bourgaei Boiss. Evid-Based Complementary Altern Med 2013; 2013: 293080

[65] Hanoğlu A, Yiğit Hanoğlu D, Demirci B, Özkum Yavuz D, Başer KHC, Çalış I. Essential oil composition of leaves and flowers of two endemic Phlomis L. species (Phlomis cypria post and Phlomis brevibracteata Turrill) from Northern Cyprus. J Essent Oil Res 2019; 31: 196-202

[66] Çelik S, Göktürk RS, Flamini G, Cioni PL, Morelli I. Essential oils of Phlomis leucophracta, Phlomis chimerae and Phlomis grandiflora var. grandiflora from Turkey. Biochem Syst Ecol 2005; 33: 617-623

[67] Özcan MM, Chalchat JC, Bağcı Y, Dural H, Figueredo G, Savran A. Chemical composition of essential oils of Phlomis grandiflora HS Thompson var. grandiflora flowers and leaves of Turkish origin. J Food Biochem 2011; 35: $125-132$

[68] Demirci F, Güven K, Demirci B, Dadandı MY, Başer KHC. Antibacterial activity of two Phlomis essential oils against food pathogens. Food Control 2008; 19: 1159-1164

[69] Doğan G. Chemical composition of essential oils of four Phlomis species from Turkey: a chemotaxonomic approach. Bangladesh J Botany 2017; 46: $823-830$

[70] Demirci B, Dadandı MY, Paper DH, Franz G, Başer KHC. Chemical composition of the essential oil of Phlomis linearis Boiss. \& Bal., and biological effects on the CAM-assay: a safety evaluation. Z Naturforsch C 2003; 58: $826-829$

[71] Sarıkaya AG, Fakir H. Effects of reaping time on volatile components of natural Phlomis rigida Labill. and Phlomis monocephala P.H. Davis in Turkey. Applied Ecol Environ Res 2019; 17: 1923-1928

[72] Kırımer N, Başer KHC, Kürkçüoğlu M. Composition of the essential oil of Phlomis nissolii L. J Essent Oil Res 2006; 18: 600-601

[73] Demirci B, Başer KHC, Dadandı MY. Composition of the essential oils of Phlomis rigida Labill. and Phlomis samia L. J Essent Oil Res 2006; 18: 328 331

[74] Özdemir FA, Kılıç O, Yıldırımlı S. Essential oil composition and antimicrobial activity of endemic Phlomis sieheana Rech. from Bingol, Turkey. J Essent Oil Bear Plants 2017; 20: 516-523

[75] Sarıkürkçü C, Zeljkovic SC. Chemical composition and antioxidant activity of Phlomis leucophracta, an endemic species from Turkey. Nat Prod Res 2020; 34: 851-854

[76] Lawrence MB. Labiatae Oils-Mother Nature's chemical Factory. In: Lawrence MB, ed. Essential Oils. Carol Stream: Allured Publishing Co; 1993: 188-197

[77] Bianco A, Guiso M, lavarone C, Marini-Bettolo R, Trogolo C. Fulvoiridoids. 4-methoxycarbonyl-7-methylcyclopentac]pyran from ipolamiide. Gazz Chim Ital 1976; 106: 733-741

[78] Viccini LF, Silva PS, de Almeida MV, Saraiva MF, Peixoto PHP, Salimena FRG, Diniz R, Rodriguez BL, Scowen I, Edwards HGM, de Oliveira LFC. Ipolamiide and fulvoipolamiide from Stachytarpheta glabra (Verbenaceae): a structural and spectroscopic characterization. J Mol Struct 2008; 875: 27-31

[79] Zohary M, Feinbrun-Dothan N. “Eremostachys BUNGE” in Flora Palaestina. Jerusalem: The Israel Academy of Sciences and Humanities; 1978; Part Three: 117

[80] Çalıs I, Güvenç A, Armağan M, Koyuncu M, Gotfredsen CH, Jensen SR. Iridoid glucosides from Eremostachys moluccelloides Bunge. Helv Chim Acta 2007; 90: 1461-1466

[81] Güvenç A, Armağan M, Koyuncu M, Gotfredsen CH, Jensen SR. Secondary metabolites from Eremostachys laciniata. Nat Prod Comm 2008; 3: $117-124$
[82] Mathiesen C. Phylogeny and biogeography of the lamioid mint genus Phlomis L. [Candiata Scientiarum Thesis]. Oslo, Norway: Natural History Museum, University of Oslo; 2006

[83] Saracaoğlu I, Çalış I, Inoue M, Ogihara Y. Selective cytotoxic and cytostatic activity of some phenylpropanoid glycosides. Fitoterapia 1997; LXVIII; 433-438

[84] Heilmann J, Çalıs İ, Kirmizibekmez H, Schühly W, Harput S, Sticher O. Radical scavenger activity of phenylethanoid glycosides in FLMP stimulated human polymorphonuclear leucocytes-structure activity relationships. Planta Med 2000; 66: 746-748

[85] Çalış i. Biodiversity of Phenylethanoid Glycosides. In: Şener B, ed. Biodiversity. Biomolecular Aspects of Biodiversity and innovative Utilization. New York: Kluwer Academic/Plenum Publishers; 2002: 137-149

[86] Inoue M, Sakuma Z, Ogihara Y, Saracoğlu I. Induction of apoptotic cell death in HL-60 cells by acteoside, a phenylpropanoid glycoside. Biol Pharm Bull 1998; 21: 81-83

[87] Ohno T, Inoue M, Ogihara Y, Saracoğlu i. Antimetastatic activity of acteoside, a phenylethanoid glycoside. Biol Pharm Bull 2002; 25: 666-668

[88] Akcos Y, Ezer N, Çalış I, Demirdamar R, Tel BC. Polyphenolic compounds of Sideritis lycia: and their anti-inflammatory activity. Pharm Biol 1999; 37: 118-122

[89] Akbay P, Çalıs İ, Ündeğer Ü, Başaran N, Başaran AA. In vitro immunomodulatory activity of verbascoside from Nepeta ucrainica L. Phytother Res 2002; 16: 593-595

[90] Tandoğan B, Güvenç A, Çalış I, Ulusu NN. In vitro effects of isoorientin, forsythoside $B$, and verbascoside on Bovine kidney cortex glutathione reductase. Int J Chem Kinetics 2013; 45: 574-579

[91] Ismailoglu UB, Saracoğlu İ, Harput US, Sahin-Erdemli I. Effects of phenylpropanoid and iridoid glycosides on free radical-induced impairment of endothelium-dependent relaxation in rat aortic rings. J Ethnopharmacol 2002; 79: 193-197

[92] Sheng GQ, Zhang JR, Pu XP, Ma J, Li CL. Protective effect of verbascoside on 1-methyl-4-phenylpyridinium ion-induced neurotoxicity in PC12 cells. Eur J Pharmacol 2002; 451: 119-124

[93] Alipieva K, Korkina L, Orhan IE, Georgiev MI. Verbascoside-a review of its occurrence, (bio)synthesis and pharmacological significance. Biotechnol Adv 2014; 32: 1065-1076

[94] Xue Z, Yang B. Phenylethanoid glycosides: research advances in their phytochemistry, pharmacological activity and pharmacokinetics. Molecules 2016; 21: 991

[95] Tian XY, Li MX, Lin T, Qiu Y, Zhu YT, Li XL, Tao WD, Peng P, Ren XX, Chen LP. A review on the structure and pharmacological activity of phenylethanoid glycosides. Eur J Med Chemistry 2020; 209: 112563

[96] Alipieva KI, Jensen SR, Franzyk H, Handjieva NV, Evstatieva LN. Iridoid glucosides from Phlomis tuberosa L. and Phlomis herba-ventis L. Z Naturforsch 2000; 55c: 137-140

[97] Liu P, Yao Z, Li HQ, Duan HQ. Four new nortriterpenoids from Phlomis umbrosa. Helv Chim Acta 2007; 90: 601-606

[98] Liu P, Li LY, Niu RQ, Yin WP, Zhao TZ. Two novel nortriterpenes from the roots of Phlomis umbrosa. Chin Chem Lett 2008; 19: 1228-1230

[99] Liu P, Yao Z, Zhang W, Takaishi Y, Duan HQ. A novel nortriterpenes from Phlomis umbrosa. Chem Pharm Bull 2008; 56: 951-955

[100] Tjitraresmi A, Moektiwardoyo M, Susilawati Y, Shiono Y. Antimalarial activity of Lamiaceae family plants: review. Sys Rev Pharm 2020; 11: 324-333

[101] Abdelaty NA, Attia EZ, Hamed ANE, Desoukey SY. A review on various classes of secondary metabolites and biological activities of Lamiaceae (Labiatae) (2002-2018). J Adv Biomed Pharm Sci 2021; 4: 1-16 